\title{
Beyond Individual Lives: Using Comparative Osteobiography to Trace Social Patterns in Classical Italy
}

\author{
John Robba*

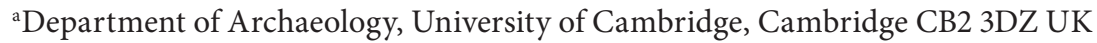 \\ *Correspondence to: John Robb, Department of Archaeology, University of Cambridge, Downing Street, \\ Cambridge CB2 3DZ, UK \\ e-mail: jer39@cam.ac.uk
}

ABSTRACT

Osteobiographical studies have usually focused upon investigating an individual's life experience. However, we can also understand variation in the shape of the life course itself as an object of study: Are there common patterns for how lives unfold within a society? Are there events or experiences that channel life courses? This approach to the life course can be adopted for ancient as well as for modern lives. A key element here is developing new methodologies for characterizing and comparing how lives develop through time, for instance, by ordering biological data in sequence, looking for time-structured patterns in them both by eye and through multivariate statistics. This article presents an initial exploration of this problem, using skeletal and archaeological data on 47 adults from the fifth to third centuries B.C. at Pontecagnano, an urban site in Campania, Italy. The results show both the importance of gender in the life course and the effects of different kinds of physical stress, probably due to specialization in labor. The result is not discrete categories of people but fuzzy envelopes of life possibilities.

Keywords: biography; gender; work; Italy; Etruscan; specialization; life course

Los estudios osteobiográficos se han enfocado generalmente en la investigación de la experiencia vital del individuo. Sin embargo, también podemos comprender la variación en la forma del curso mismo de la vida como objeto de estudio: ¿existen patrones comunes (que demuestran) cómo se desarrollan las vidas (individuales) dentro de una sociedad? ¿Existen eventos o experiencias que canalizan los cursos de vida? Esta aproximación al curso de la vida puede ser adoptada tanto para las vidas ancianas como las modernas. Un elemento clave (en esto) es el desarrollo de nuevas metodologías para caracterizar y comparar cómo se desarrollan las vidas a través del tiempo, por ejemplo al ordenar datos biológicos en secuencia y buscar en ellos patrones estructurados en el tiempo tanto (visualmente/por vista) como a través de estadísticas multivariadas. Esta investigación presenta una exploración inicial de este problema utilizando los datos esqueléticos y arqueológicos de 47 (cuarenta y siete) adultos del 50 al 3er siglo a.C. en Pontecagnano, un sitio urbano en Campania, Italia. Los resultados demuestran tanto la importancia del género en el curso de la vida como los efectos de diferentes tipos de estrés físico, debido con toda probabilidad a la especialización laboral. (Esto no resulta) en categorías discretas de personas sino en sobres difusos de posibilidades de la vida.

Keywords: biografia; género; trabajo; Italia; Etrusco; especialización; curso de vida 


\section{Social Process, Human Life Courses, and Osteobiography}

Human lives are not mechanical or deterministic, but neither are they simply concatenations of random events. Instead, they have a temporal structure; earlier events shape the possibilities of later ones. This is abundantly clear in familiar, everyday examples: an educational opportunity, the death of a parent, a pregnancy, or a serious health episode can shape someone's entire subsequent life trajectory. Moreover, as natives of our own culture we often have a conscious sense of how different kinds of people have distinct events, opportunities, and life tracks. Patterning in the actual lives people lead often exists in the context of cultural narratives about how the "normal" human life span is supposed to go, even if many people do not achieve the ideal "good life." Tracking any cohort, whether a formal long-term cross-sectional study or your high school graduating class on Facebook, shows both how recurrent life patterns emerge from social process and how any individual life has its own trajectory, sometimes taking quite unexpected directions. If we think of lives as vibrant lines extending themselves through time, they do not follow a rigid channel, but nor do they zoom off in random directions. Instead, as they wander through the possibility spaces their social and historical setting affords them, they unfold in loose skeins or bundles.

The temporal structure of human lives has been studied principally in fields such as public health, sociological life-course studies, and biography (see Hosek and Robb, this issue). These studies bridge the gap between individual lived lives and macro-patterns in society as a whole. At the other end of the pole, ethnographers often use narratives of individual lives, taking a single informant's story as a microhistory exposing social issues (see Hosek, this issue). Novelists do so as well; for example, Thomas Hardy's Tess of the d'Urbervilles both explores the effect of gendered events upon an individual woman's life story and shows how Tess stands for women as a category within a patriarchal society. In bioarchaeology, osteobiography can accomplish similar goals, letting us assemble facts into life narratives and highlighting the continuity or coherence among all the facts of a human life over time. The key concepts are reviewed above (Hosek and Robb, this issue) but can be mentioned here (see also Boutin et al. 2012; Saul and Saul 1989; Stodder and Palkovich 2012). Throughout life, the body as a physical structure is constantly changing in response to age and environment (Agarwal and Beauchesne 2011). Thus, as advocated in the life-course approach, its history can be read as a record of the stresses and risks experienced at different ages (Agarwal 2016;
Glencross 2012). Reciprocally, people interpret changes in their bodies as signifiers of social age, which may be more important than chronological age (Appleby 2011; Sofaer 2011); indeed, they often go beyond interpreting their bodies, intervening directly and intentionally to modify them or changing their activities in ways that alter their bodies. The body can thus be considered as material culture, as something shaped by the ongoing course of social life (Sofaer 2006). This line of thought has been developed archaeologically principally in the idea of childhood, adulthood, and old age as culturally understood stages of life (Appleby 2011; Halcrow and Tayles 2011; Lewis 2007; Sofaer 2000), but it is also clear that the overall normative biography forms a powerful cultural narrative (Robb 2002).

But osteobiography has almost always remained at the level of the individual, telling a single life story (with rare exceptions; see Barrett and Blakey 2011). It has tackled questions of the shape of human lives only by asserting, explicitly or implicitly, that the individuals studied are typical of their time, or group, or class or gender, and thus their life story also tells us something about their social world. This is useful, but we could go much further. Some key questions are:

- Within a human life, are there systematic patterns in how earlier events affect later events?

- Within a group, are there recurrent patterns in how lives unfold-what events people experience, when they experience them, and what their effects are?

- Do people in different groups (genders, classes, ethnicities, occupations, religions, etc.) experience different lives? If so, why?

To answer these, we need to approach osteobiography differently. Osteobiography has typically involved writing individual lives in as much detail as possible. But we can also go "meta," lining up osteobiographies side by side to examine how individual individual lives are when we aggregate them, how much they really do form tight bundles adhering to narrow life paths or wander loosely through life's possibilities. Intuitively, we might expect to observe people's lives being played out within fuzzy envelopes, neither tightly deterministic nor unstructured, perhaps with distinct tracks for people differentiated by category and social position or by major life choices such as going to university or experiencing a major illness. But is this really so?

Although new territory for bioarchaeology, such issues have been explored in fields such as sociological life-course studies(Heinz and Krüger 2001). Such studies, however, give us mostly reassurance that the shape of human lives is an intellectually important problem worth studying; bioarchaeological data are so different from the data sociologists use that by and 
large we have to devise our own methods rather than borrowing them from other fields. This article is an attempt to do so. Interestingly, this requires thinking not only about statistical methods but about pictures as well. Osteobiographies involve assembling complex arrays of quite different kinds of data. It is not only the values but the relations between them in multivariate space that are most telling. To make them comprehensible, we need to simplify the data carefully and group them in a way that reveals both patterns and variation. While exploratory multivariate statistics such as clustering or network analysis could be used, we need to integrate categorical, ordinal, and numerical data, and usually any individual is missing at least some data. The alternative approach used here is to accept this as an imaginative challenge and to experiment with new graphs or charts for visualizing human lives.

This article argues that individual human lives have shapes or courses and that the shape of human lives in themselves may be important and informative when studied in the aggregate. It presents a first try at exploring the comparative study of the human life course in a past society. Using data from 47 adults from the ancient city of Pontecagnano (fifth-third centuries B.C.), I try to outline some common life patterns. The analysis is exploratory. It succeeds in outlining some possible variation in how men's and women's life courses unfolded, but more importantly, its real goal is to raise the possibility of this kind of approach and to stimulate further work on it.

\section{Pontecagnano: Life and Death in an Early Urban Society}

The town of Pontecagnano is located in southern Italy, near the Tyrrhenian coast south of Naples and Salerno (Fig. 1). It was founded around 800 B.C. and has been continuously occupied since then. Its Oscan-speaking population was formed of native Italic peoples, but with strong influence from both Greeks and Etruscans. The town's social structure and culture changed substantially between the eighth and third centuries B.C. as it became increasingly urban, class-based, and integrated with the larger Mediterranean world. In the period studied here the town was almost a kilometer square, with a fortification wall, a dense grid street plan, a sacral area, artisan neighborhoods, residential areas, and multiple extramural cemeteries (Alfano et al. 2006). Until its takeover by Rome in the third century B.C., the town participated fully in the cultural koine of the pre-Roman Classical world (d'Agostino 1974). Over the last 50 years, classical remains from Pontecagnano have been extensively excavated, particularly the cemeteries, with substantial bioarchaeological work done (Cencetti 1989; Fornaciari et al. 1984, 1986;
Lombardi Pardini et al. 1984, 1992; Mallegni et al. 1984; Eduardo Pardini et al. 1983; Elena Pardini et al. 1982; Petrone 1995; Robb et al. 2001; Scarsini and Bigazzi 1995; Serritella 1995; Sonego 1991; Sonego and Scarsini 1994). This study analyzes a homogeneous sample of skeletons from a period of about 10 generations between the fifth and earlier third centuries B.C.

In understanding the biographies of these people, two features of social context are critical. First, gender was a key organizing principle of classical culture. Classical gender was mostly binary; it was tied closely to biological sex, and it conditioned many aspects of adult life (Foxhall 2013; Robb and Harris 2013:chapter 4 and references therein). In Pontecagnano burials, for instance, with a few exceptions there is generally good agreement between skeletal sex and the stereotypical "male" and "female" grave goods (see below). Males and females officially became adults between about 15 and 20 years of age, upon marriage for women and when legally recognized as a man around 18 for men (Golden 2003); however, they probably began to engage in adult work before this as their capabilities allowed. Second, like most or all sizable classical towns, Pontecagnano was class-stratified; its cemeteries reveal a range of wealth. The samples here comprise mostly the lower-middle range of society; while they do not contain the wealthiest individuals, they consist of people buried in the normal way with standard rites, which usually consisted of burial in a simple pit or tile-covered grave with a few inexpensive grave goods, mostly ordinary pottery vessels. A sizeble classical town such as Pontecagnano had a complex division of labor, with a wide range of specialized workers and craftspeople. Many people's work regimes would have involved generalized or varied tasks, particularly farmworkers and unskilled laborers. But dozens of job specializations were known in both Greek and Roman society; even in a small city such as Pontecagnano, specialized workers would have included porters, stone masons, builders, potters, tile and brick makers, weavers, tailors, shoemakers and other leatherworkers, smiths and metalworkers, carpenters, carters, mule drivers, herders, cooks, and merchants of all sorts of goods. Some people buried here may also have engaged in specialized work done elsewhere, for instance, sailors. Some of these occupations were engaged in by both free people and enslaved people. Women in the classical world often carried out gendered tasks associated with the household, including heavy work such as carrying water; they were normatively associated with spinning and weaving. But they are also known to have carried out activities such as running businesses, and poorer women often did agricultural labor. These two factors suggest that we should expect some differentiation in life courses, both from gender and from the specific activities they 


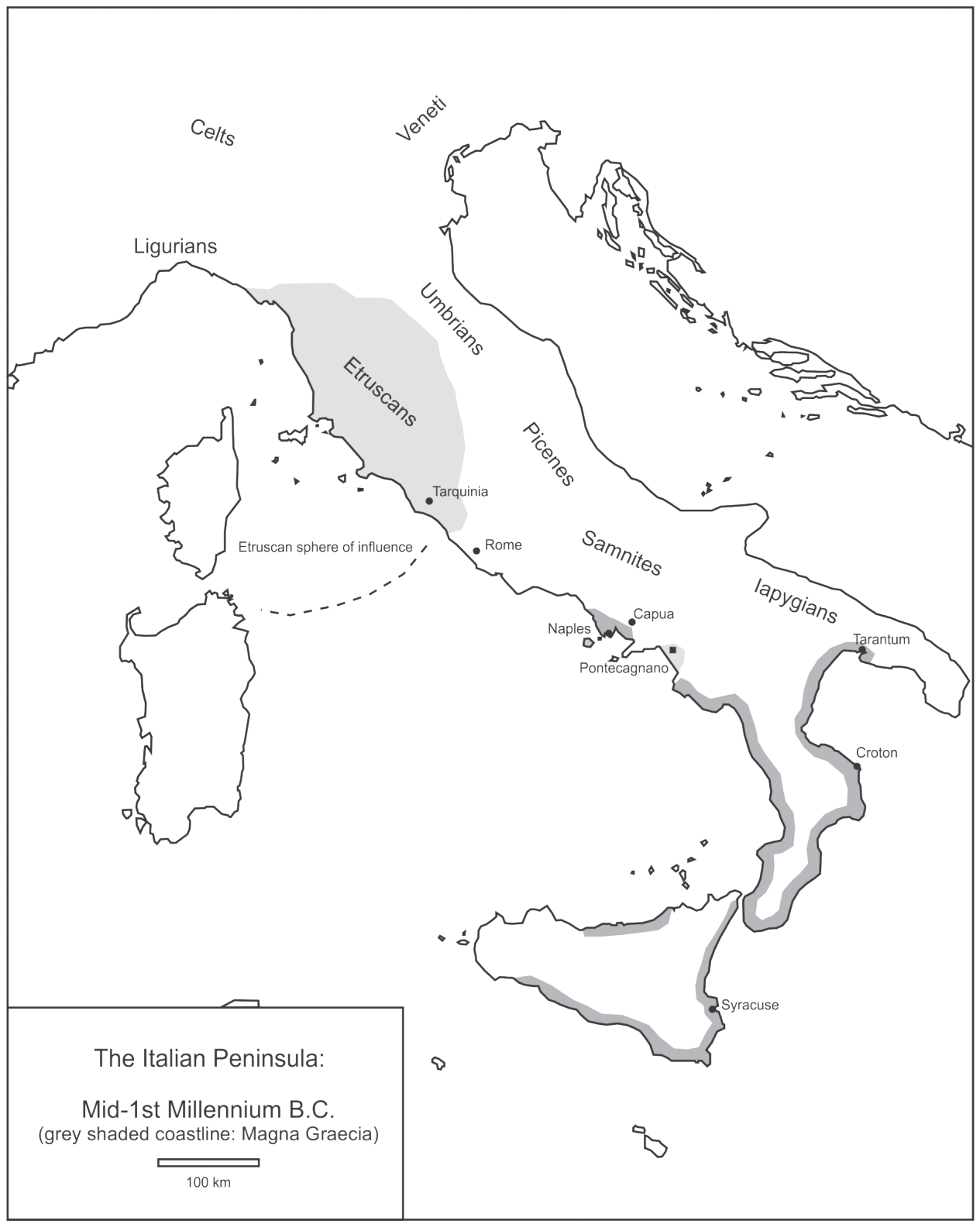

Figure 1. Location of Pontecagnano within southern Italy, ca. 500-300 B.C.

performed. Indeed, the two factors intersected; throughout the ancient world, men engaged in a much wider range of specialized jobs than did women (Foxhall 2013:96-101).

\section{Materials and Methods}

\section{Analytical strategy for comparative osteobiography}

The analytical strategy needed for comparative osteobiography is straightforward, even if some aspects present challenges for skeletal data. A first principle is keeping all data within their context: any individual in our data sets must be seen relative to all the others, leading us to constantly alternate between outlining a general pattern and asking how an individual under study relates to it. A second principle is sequence, arranging events within each life in temporal order. In historical or sociological biographies with well-dated life records, this may be done with precision. With skeletal data we normally have to arrange events in bucket categories such as childhood and adulthood, without ordering events within these intervals. In this study, data were assigned to broad stages of the life span (Table 1). This included not only biological data but archaeological data as well; funerary treatment 
Table 1. Selected skeletal data for moments in the human life span, listing indicators used in this study.

\begin{tabular}{|c|c|c|}
\hline Life Stage & Data & Groupings Used in Table 2 and Figure 7 \\
\hline Birth & $\begin{array}{l}\text { Sex (assigning social gender) (Buikstra and Ubelaker 1994; } \\
\text { Workshop of European Anthropologists 1980) }\end{array}$ & Male, female \\
\hline \multirow[t]{3}{*}{ Childhood } & $\begin{array}{l}\text { Enamel hypoplasia, total number of lesions observed on all teeth } \\
\text { in dentition macroscopically using strong oblique light } \\
\text { (Goodman and Rose 1991) }\end{array}$ & 1 lesion, $2-3$ lesions, $4+$ lesions \\
\hline & Cribra orbitalia (Buikstra and Ubelaker 1994) & Present / absent \\
\hline & $\begin{array}{l}\text { Stature achieved by adulthood; estimated using all available long } \\
\text { bones (Trotter and Gleser 1958) }\end{array}$ & $\begin{array}{l}\text { Lower } 1 / 4 \text { of male or female range, middle of male or } \\
\text { female range, upper } 1 / 4 \text { of male or female range }\end{array}$ \\
\hline \multirow[t]{7}{*}{ Adult life } & $\begin{array}{l}\text { Traumas as evidence of life risks, identified macroscopically } \\
\text { (Ortner and Aufderheide 1991; Ortner and Putschar 1981; for more } \\
\text { detail on trauma in this collection, see Robb 1997) }\end{array}$ & Present/ absent \\
\hline & Dental disease (caries, antemortem tooth loss) & Presence/absence \\
\hline & $\begin{array}{l}\text { Schmorl's nodes, number of vertebrae affected (Ortner and } \\
\text { Putschar 1981) }\end{array}$ & $0,1-4,5-7,8+$ \\
\hline & $\begin{array}{l}\text { New bone growth (Ortner and Aufderheide 1991; Ortner and } \\
\text { Putschar 1981; cf. Weston 2012) }\end{array}$ & $\begin{array}{l}\text { "periostitis": present/absent anywhere in the skeleton } \\
\text { "tibial periostitis": present/ absent in the tibia(s) }\end{array}$ \\
\hline & $\begin{array}{l}\text { Arthropathies as evidence of habitual activity (Rogers and } \\
\text { Waldron 1995; Rogers et al. 1987; cf. Waldron 2012) }\end{array}$ & $\begin{array}{l}\text { "osteoarthritis": presence or absence of marginal bone } \\
\text { proliferation, porosity and eburnation } \\
\text { "eburnation": presence or absence of eburnated surfaces }\end{array}$ \\
\hline & $\begin{array}{l}\text { Entheseal variation as evidence of habitual activity (recorded as } \\
\text { grades of expression between } 1 \text { and 5, with average entheseal score } \\
\text { used to characterize overall skeleton) (Hawkey and Merbs 1995; } \\
\text { Robb 1998) (cf. Fig. 2) }\end{array}$ & $\begin{array}{l}\text { Mean entheseal score, grouped into lower } 1 / 4 \text { of male or } \\
\text { female range, middle of male or female range, upper } 1 \frac{1 / 4}{4} \\
\text { of male or female range }\end{array}$ \\
\hline & $\begin{array}{l}\text { Traits potentially related to specialized activity (see text for } \\
\text { explanation) }\end{array}$ & $\begin{array}{l}\text { "specialized activity: presence/ absence of several } \\
\text { relevant traits" }\end{array}$ \\
\hline Death & $\begin{array}{l}\text { Age at death, representing longevity and mortality as conditioned } \\
\text { by social factors (Buikstra and Ubelaker 1994; Workshop of } \\
\text { European Anthropologists 1980) }\end{array}$ & Decade of age at death \\
\hline \multirow[t]{2}{*}{ Treatment at death } & $\begin{array}{l}\text { Total pottery vessels deposited in the grave (Fig. } 6 \text {, Table } 2 \text { : } \\
0 \text { vessels, } 1-5 \text { vessels, } 6+\text { vessels) }\end{array}$ & 0 vessels, $1-5$ vessels, $6+$ vessels \\
\hline & Grave goods other than pottery & $\begin{array}{l}\text { Presence or absence of grave goods other than pottery } \\
\text { Presence or absence of specifically "female" ornaments } \\
\text { Presence or absence of specifically "male" objects } \\
\text { (weapons, armour, strigils) } \\
\text { Presence or absence of other objects }\end{array}$ \\
\hline
\end{tabular}

reveals a social response following the moment of death.

In analyzing the data, two questions are key:

1. At each stage of life, do the data reveal discrete groupings into people whose lives were situated differently? Or do they reveal a continuum of variation, or no patterned variation at all?

2. How do events or groupings at earlier life stages influence events or groupings at later life stages?

Statistically, one could imagine exploring these questions formally using exploratory multivariate analyses (as indeed is sometimes done with sociological data). However, as a preliminary foray it is appropriate here to use a straightforward, more intuitive combination of traditional descriptive statistics, simple inferential statistics such as chi-square and t-test analyses, and visual representations.

\section{Materials and skeletal methods}

Detailed osteobiographical data on people from Pontecagnano were collected by the author in the Museo Nazionale di Antropologia, Firenze, in 1991 and 1992. While hundreds of skeletons from the site have been studied (Cencetti 1989; Fornaciari et al. 1984, 1986; Lombardi Pardini et al. 1984, 1992; Mallegni et al. 1984; Eduardo Pardini et al. 1983; Elena Pardini et al. 1982; Petrone 1995; Robb et al. 2001; Scarsini and Bigazzi 1995; Serritella 1995; Sonego 1991; Sonego and Scarsini 1994), to exclude the effects of historical change, the skeletons chosen for analysis here include a homogeneous sample from the later fifth to early 
third centuries B.C. Only skeletons well enough preserved to afford mostly complete data were used, and only skeletons with a full range of data collected by a single observer were used. To maximize the biographical information available, only adult skeletons were included in this analysis. A wide range of data were collected: sex, age, stature, and pathologies, nonpathological variations, and signs of activities. Details of data collected and the relevant standards used are presented in Table 1.

It is important to realize that, to some extent, this study uses legacy data which reflects the state of the field in the early 1990s. This is evident in what is not included: although most modern osteobiographies would include light stable isotopic and ancient genetic data, these data are not available here. For some other methods, either data collection standards or interpretations have moved on substantially, and consequently these data are omitted here (e.g., studies of biodistance using metrics and nonmetrics; interpretations of activity based upon external bone measurements rather than scan data; pelvic observations once considered related to parturition). Many basic standards have changed relatively little (e.g., for aging, sexing, stature estimation, macroscopic recording of linear enamel hypoplasia, presence of activity-related skeletal variations, and trauma). Observation and recording of most paleopathologies remain commensurate, even as interpretations of some have changed. The most rapidly developing methodologies are for entheseal markings (Fig. 2), with some researchers using ordinal categories analyzed statistically (Hawkey and Merbs 1995; Weiss 1999, 2007) and others using the "Coimbra" system (Henderson et al. 2016). Even these efforts fail to reflect the biological complexity of muscle attachment sites, and a satisfactory solution has yet to be reached (Villotte and Knüsel 2013). The data presented here use standards similar to the former, resulting in ordinal grades expressing the full range of morphological variation at an entheseal site (Robb 1998). Although in some cases one might employ updated standards in a study designed today, the data selected for analysis here are those that are stable and commensurate with standards used today, and they serve effectively to illustrate the approach pioneered here. Perhaps the biggest shift in methods and interpretation since 1990 involves issues raised by the "osteological paradox" (Wood et al. 1992); the extent to which skeletal phenomena may be age-related is fundamental to biography and has been taken into consideration throughout the interpretations presented here.

Analyzing the data collected presents other challenges. Some data lack standardized or conventional forms of analysis (e.g., does one tabulate osteoarthritis by joint surface, by bone, or by joint?). In this study, data are analyzed contextually in ways most effective

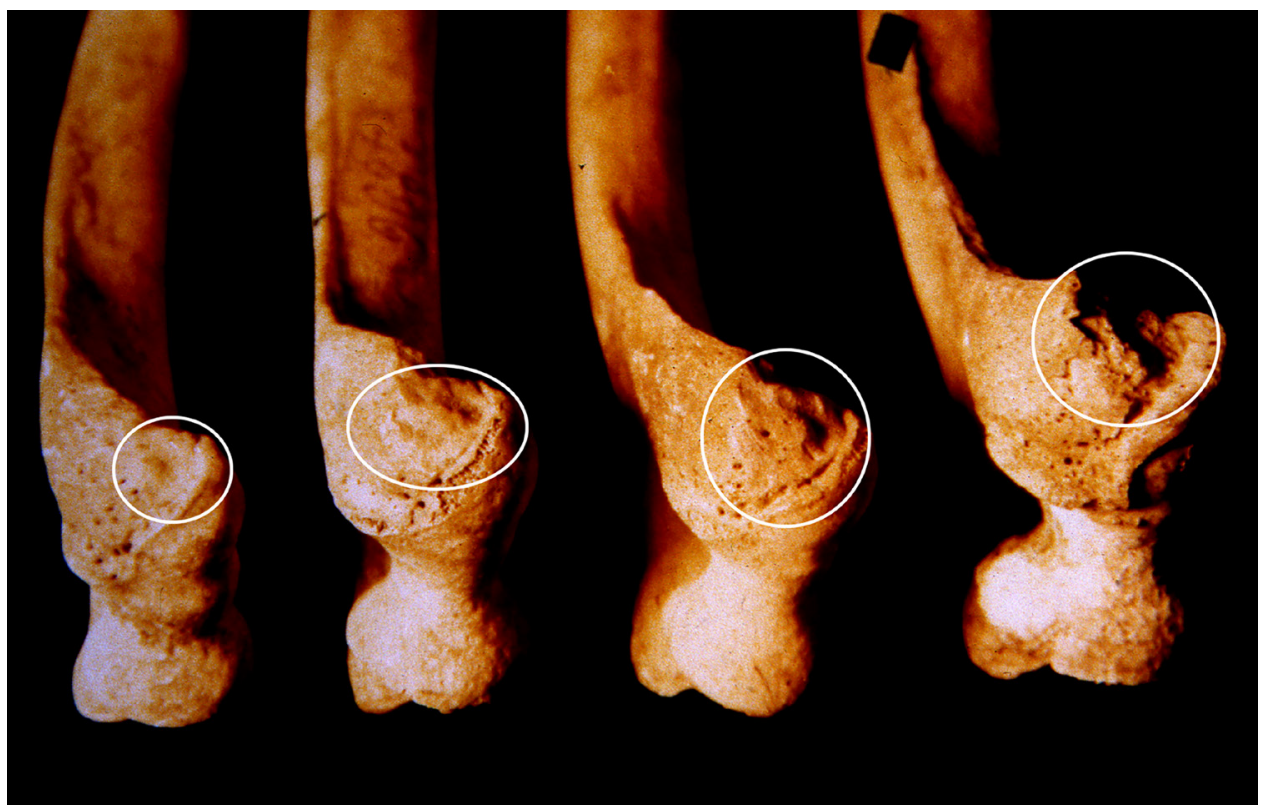

Fig. 2. Example of standards used to record entheseal marking variation for the common extensors origin, lateral epicondyle of distal humerus. Grade 1: no trace of marking visible (not illustrated). Left to right: Grade 2: small facet is visible; rim of facet is finely rugose and may be indistinct in places, and surface of facet is smooth. Grade 3: facet is larger and well bounded on all sides; rim may be slightly raised, and surface is smooth or finely rugose. Grade 4: facet is large, covering much of the surface of medial epicondyle; surface may be rugose or rugged, and border is unclear due to rugosity or surface destruction. Grade 5: osteophytes; a small protuberance below the edge of the medial epicondyle may be present. 
for this sample and question. For example, both enamel hypoplasia and Schmorl's nodes were very common in this group, and simply registering them as present or absent does little to highlight variation among individuals; tabulating the number of lesions or using a range of incremental bins proved more revealing. Similarly, it seems probable that, in this collection, periosteal deposition on the tibia resulted partly from different causes and had a somewhat different distribution than periosteal deposition elsewhere in the skeleton, and thus the two were analyzed separately. Such methodological judgments need to be grounded in the specific nature of each sample analyzed.

\section{Bodies shaped by work: Signs of labor}

One category of data proved particularly important to this project. Work and activity are one fundamental route by which social position and identity intervene in a person's life story; they also deeply shape the evidence of the body (Capasso et al. 1999; Jurmain 1998; Jurmain et al. 2012; Kennedy 1989, 1998; Merbs 1983; Robb 1994; Sofaer 2006; Weiss 1999). This is true above all for historical contexts in which there was a highly specialized division of labor but most people still performed strenuous manual work. It is no surprise that it was Victorian physicians such as W. A. Lane (Kennedy 1989) who began to recognize occupationally induced morphologies, fractures, arthropathies, and pathologies. Similar conditions characterized life in ancient cities such as Pontecagnano. As this insight would suggest, in the skeletons under study it was common to encounter people with highly idiosyncratic patterns of functional modifications, arthropathies, entheseal changes, and gross morphology. These skeletal signs were often markedly different or unique, rather than simply extreme manifestations of conditions common to many people, suggesting that at least in some cases, they must represent some functionally stressful activity that affected a few individuals to a great extent and others little or not at all. To take one example, several individuals in this sample displayed strongly lateralized eburnation and asymmetry in the cervical vertebrae, which suggested that the neck was habitually compressed sideways. This would be compatible with habitually carrying a heavy load such as a block of stone, a bale of goods, or an amphora on one shoulder, with the neck and body bent sideways to stabilize the load and keep the center of gravity over the base of the spine.

Trying to identify the specific activities that led to such bodily changes is rarely possible, particularly as such skeletal variations almost never respond solely to activity (see recent overview by Jurmain et al. 2012). But, given the range of specialized manual occupations known in ancient cities, we should expect that many people in Pontecagnano habitually performed stressful, specialized labor, and this would result in skeletons with marked, idiosyncratic patterns of pathology and functional change. This is a classic example of something osteologists can readily intuit while studying a collection but for which we have no developed methods for analyzing systematically. Standard protocols exist for recording data on entheseal markings, osteoarthritis, and some functional variations such as supernumerary facets in joints. But many observable, possibly functional variations have never actually been studied, and those that have been studied respond to multiple causes. To take an example, Schmorl's nodes are small lesions on vertebral bodies where bone has resorbed around a herniated intervertebral disk; they may reflect axial loading or spinal trauma, and they are sometimes but not always associated with lower back pain. Some authors consider Schmorl's nodes simply an age-related degenerative symptom (Buikstra and Ubelaker 1994:121) even though they are often seen in young adults; others cautiously admit that they may be related to work and activity stress (Jurmain 1998:166), while yet others consider them clearly related to mechanical stress (Capasso et al. 1999:38; Mann and Murphy 1990:52) or to vertebral morphology (Plomp et al. 2012, 2015). Clinical reviews suggest that they are multifactorial in origin, but functional loading is one important factor, particularly in younger patients (Kyere et al. 2012; Mattei and Rehman 2014). To add a layer of complexity, information about social process may reside in multivariate patterns, and hence simply tabulating single indicators such as one particular activity-related trait is usually insufficient. Essentially, we need a way to characterize people based upon a close reading of the texture of variation in their overall skeleton, and without regarding any single trait as diagnostic of activity.

In this study, however, simply as a proof of concept, a simple, direct approach has been taken. Using the general type of evidence considered to be potential signs of activity (Capasso et al. 1999; Dutour 1986; Kennedy 1989; Merbs 1983), skeletons were identified as likely to have performed some specialized form of labor, based upon several observations (Fig. 3):

- Idiosyncratic arthropathies, such as localized eburnation: for instance, one skeleton displayed bilateral eburnation on the articular surface of the coronoid process of the ulna, suggesting stressful forces pulling upon the forearms at full extension. Similarly, several skeletons displayed ankylosis of the first rib and sternum. 
- Functional modifications: Besides nonmetric traits such as facets around the joints such as hands, feet, and hips suggesting habitual positions (Finnegan 1978; Trinkaus 1975), examples include articular facets between the spinous processes on lumbar vertebrae (Kacki et al. 2011) and accessory facets within the shoulder capsule. Other examples include functional modifications such as interdental grooving probably related to craft activity.

- Morphological changes such as marked asymmetry in the thorax or vertebrae.
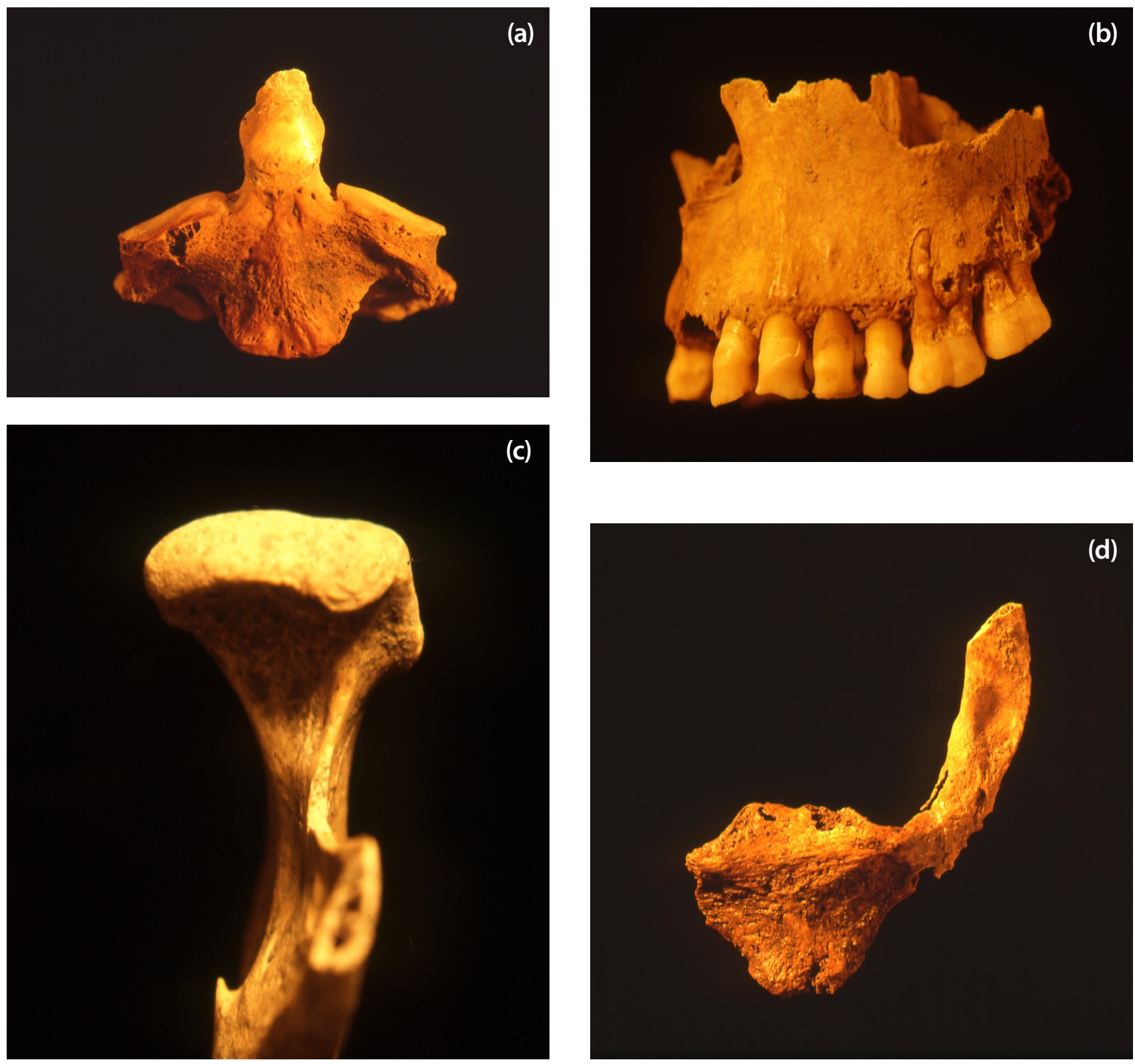

Figure 3. Examples of skeletal features considered potentially related to specialized activity: (a) eburnation, dens, $\mathrm{Cl}$ (3805); (b) interdental grooving between multiple upper teeth (3805); (c) spur at insertion of lateral pterygoid muscle, mandible (4065); (d) ankylosis of manubrium and left first rib (4021); (e) osteophyte limiting motion at coronoid process of left ulna (4040); (f) bilateral extension of proximal articular surface onto anterior surface of clavicles (4040); (g) broadened iliac crest with markedly rugose insertion of erector spinae (4040); (h) eburnation, head of first metatarsal (4040). 

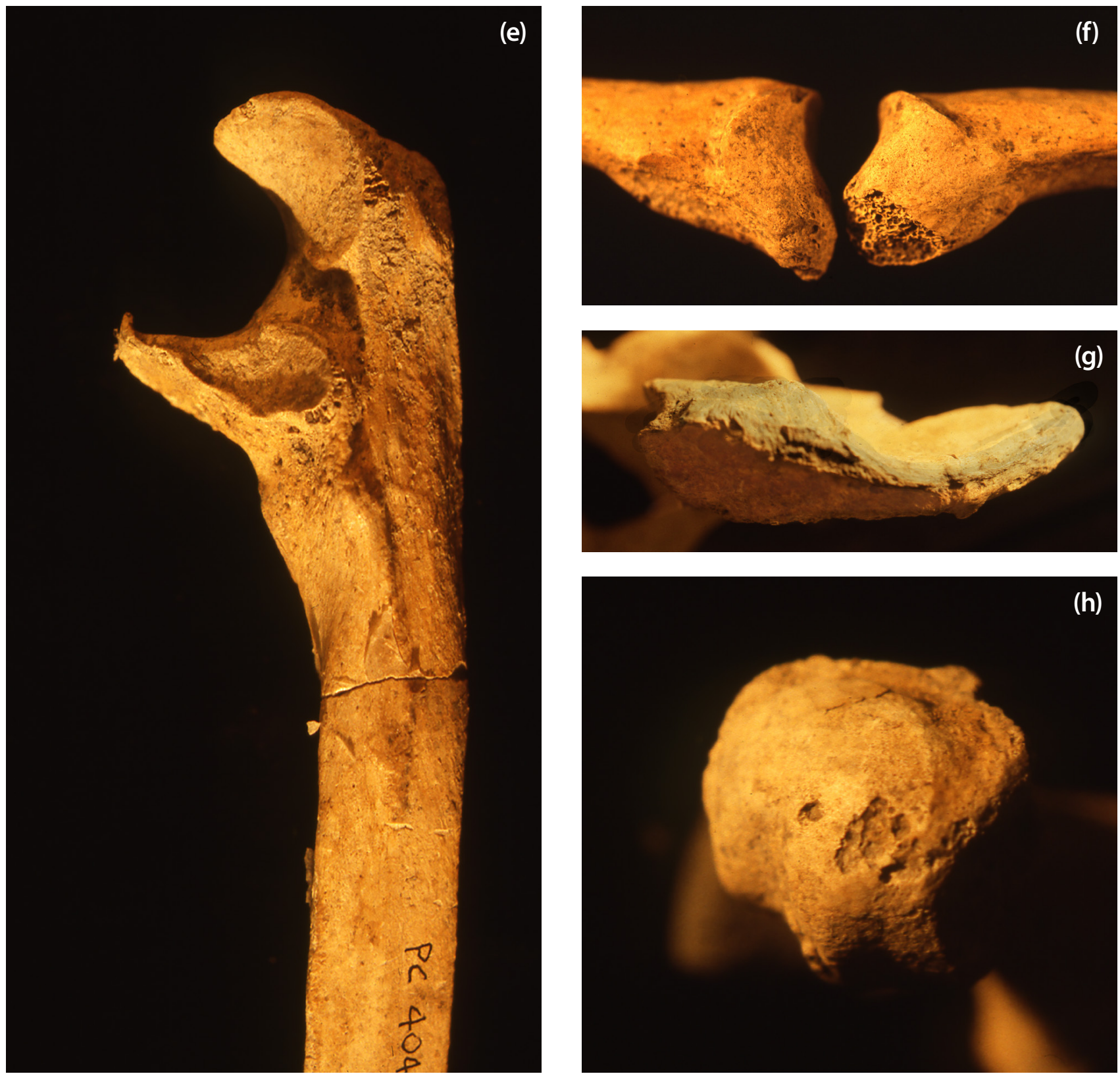

Figure 3. (Continued)

"specialist" status so as to be able to compare them to "specialization" without autocorrelation. Schmorl's nodes were also excluded from this categorization, as they occurred very commonly rather than idiosyncratically throughout the sample, suggesting a different pattern of causation (see below). As a method, this essentially formalizes a close reading of the skeleton, rather than rigorously collecting "hard" data in the traditional way. It does not claim to provide an ironclad diagnostic of specialized forms of labor (since there may be other causes behind the observed variations, and many specialized forms of work may not have left distinctive skeletal signatures); it also will bear some relationship with age, as some of the diagnostic signs of habitual activity patterns develop and become more distinct with age (this is controlled for below). But it is difficult to see any other way of addressing at least semi-systematically the patterned variation in activity indicators that the collection displays. At the level of preliminary exploration attempted here, it provides a rough-and-ready first means of characterizing variation in complex traces of habitual activity. If it provides promising results, more sophisticated methods may be developed. 


\section{The First Moment of a Social Biography: Birth, the Assignment of Gender, and Its Life Consequences}

Most aspects of birth are not accessible to us for these people. We can, however, see one social response to birth: assigning a gender to the newborn. People were ascribed a gender immediately at birth (Foxhall 2013:50). Bioarchaeologists usually consider sex as a biological given, in contrast to culturally defined gender. We cannot assume a priori that in every society, gender is mapped directly onto biological variation (Geller 2017; Hollimon 2011; Sofaer 2013). However, in Classical society, gender was closely aligned with morphological sex; it was considered mostly binary; and it was accompanied by strong expectations about gendered work and comportment. It is specifically for these reasons that I view biological sex here as a reliable proxy for social gender. Treating sex in this way allows us to see being born as a biological male or female here as the first moment in an individual's social biography, a social categorization placing the newborn on a particular social track.

This act had profound consequences throughout the life span. Women and men had quite different kinds of lives at Pontecagnano (Tables 2 and 3). Among childhood indicators, there is little difference in enamel hypoplasias; while cribra orbitalia is more frequent among women, this may indicate differing metabolic demands rather than social conditions. Gender differentiation is most marked in adult indicators of behavior. Men systematically had higher levels of Schmorl's nodes, traumatic injuries, periostitis (both generally and in the tibia), osteoarthritis (both generally and in eburnation), and entheseal markings (Table 3). Some of these differences may be ascribable to age, as there are proportionally more older males in the sample, but the male-female difference in age at death is not statistically significant $(p=0.342)$. More importantly, in women, these degenerative and accumulative indicators tend to occur in older individuals, but among men they often occur in men who died in their twenties. This suggests that the rate of wear and tear differed, with men's bodies exposed to stress and risk earlier and at a faster rate than women.

Men's and women's deaths were also responded to in different ways. Women tended to be buried with more grave goods than men. Moreover, when women were buried with things other than pottery these tended to be ornaments, while men tended to be buried with weapons, blades, elements of armor (typically a large metal belt), or strigils (a personal body-grooming accessory used in male-only world of the gymnasium).
These choices of grave goods are virtually stereotypical of gender imagery in the classical world (see Vida Navarro [1992] for similar patterns in earlier periods at Pontecagnano). Moreover, women received the most grave goods if they died in young adulthood, while men were more likely to be buried with goods if they died at older ages, perhaps reflecting increasing wealth or authority (Gnoli and Vernant 1982). This suggests that the narratives used to make sense of lives may have differed for women and men.

\section{Childhood}

Childhood must have been an important time of life, but in this sample there is little evident association between indicators of childhood health, suggesting that the experience of childhood may not have differed systematically in important ways. Nor do we observe a clear relationship between hypoplasia, stature, cribra orbitalia, and biological or social events later in life. There are several obvious reasons for this. First, this sample represents a relatively homogeneous social and economic stratum; classical towns such as Pontecagnano had extremes of wealth and poverty, but they are not represented specifically in this sample. Second, in an ancient town such as Pontecagnano, while better-off people could shield their children from some risks of harm and malnutrition, the ability to control many health risks such as illness was limited. For example, malaria was endemic in southern Italy until recent drainage works, and would have affected all sectors of ancient society. As cribra orbitalia could result from several such conditions, this may be why it does not correlate with social markers. Third, some people may have shifted their status over their lifetime (e.g., people who were born enslaved but became free). Moreover, this sample includes only people who lived to adulthood. It therefore does not contain primary evidence for one role child hood played in shaping the biography-the people dying as children who never made it to adulthood.

\section{Becoming Impaired}

Did physical impairment play a role in channeling people's lives? The sample includes three male individuals with conditions that might have affected their social presence or ability to work. The most marked case (3720) had a congenital deformity (humerus varus) that made his right arm $50 \mathrm{~mm}$ shorter than his left; he died in his twenties, with severe eburnation in his right shoulder joint, implying some long-standing 
Table 2. Biographical data on 47 adults from Pontecagnano (fifth to third centuries B.C.), colored according to categories used in analysis, and sorted by sex, life span, and Schmorl's nodes. Data are sorted by sex, then age, then Schmorl's nodes.

\begin{tabular}{|c|c|c|c|c|c|c|c|c|c|c|c|c|c|c|c|c|c|c|c|c|}
\hline \multirow[b]{2}{*}{$\begin{array}{l}\dot{\bar{\nu}} \\
\text { छี } \\
\text { z }\end{array}$} & \multirow[b]{2}{*}{ 心 } & \multicolumn{3}{|c|}{ Childhood } & \multicolumn{8}{|c|}{ Adult Experience } & \multicolumn{4}{|c|}{ Life Span } & \multicolumn{4}{|c|}{ Treatment at Death } \\
\hline & & 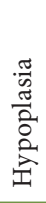 & $\frac{\pi}{\tilde{C}}$ & $\begin{array}{l}\stackrel{\Xi}{\Xi} \\
\stackrel{\Xi}{\varpi}\end{array}$ & 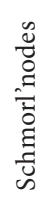 & $\underset{\stackrel{\Xi}{\Xi}}{\stackrel{\Xi}{\Xi}}$ & 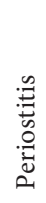 & 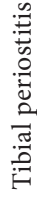 & ठే & 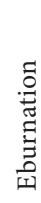 & 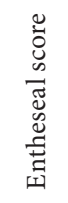 & 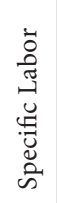 & 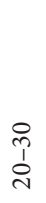 & $\begin{array}{l}0 \\
+ \\
1 \\
0 \\
0\end{array}$ & $\begin{array}{l}0 \\
\text { in } \\
1 \\
\text { of }\end{array}$ & in & 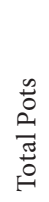 & 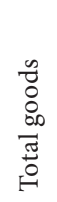 & 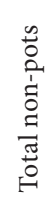 & 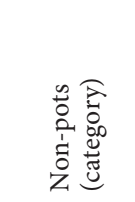 \\
\hline 3838 & $\mathrm{f}$ & 6 & $\mathrm{y}$ & 170.6 & 0 & $\mathrm{n}$ & $\mathrm{n}$ & $\mathrm{n}$ & $\mathrm{n}$ & $\mathrm{n}$ & 1.75 & $\mathrm{n}$ & $\mathrm{y}$ & & & & 0 & 0 & 0 & none \\
\hline 4094 & $\mathrm{f}$ & 3 & 1 & 152.7 & 0 & $\mathrm{n}$ & $\mathrm{n}$ & $\mathrm{n}$ & $\mathrm{n}$ & $\mathrm{n}$ & 2.23 & $\mathrm{n}$ & $\mathrm{y}$ & & & & 1 & 1 & 0 & none \\
\hline 3748 & $\mathrm{f}$ & 3 & & 155.3 & 0 & $\mathrm{n}$ & $\mathrm{n}$ & $\mathrm{n}$ & & & 2.38 & & $\mathrm{y}$ & & & & 0 & 3 & 3 & ornaments \\
\hline 4017 & $\mathrm{f}$ & 2 & $\mathrm{n}$ & & 0 & $\mathrm{n}$ & $\mathrm{n}$ & $\mathrm{n}$ & $\mathrm{n}$ & $\mathrm{n}$ & 2.18 & $\mathrm{n}$ & $\mathrm{y}$ & & & & 6 & 11 & 5 & ornaments \\
\hline 4019 & $\mathrm{f}$ & 2 & $\mathrm{n}$ & 154.6 & 0 & $\mathrm{n}$ & $\mathrm{n}$ & $\mathrm{n}$ & $\mathrm{n}$ & $\mathrm{n}$ & 2.18 & $\mathrm{n}$ & $\mathrm{y}$ & & & & 14 & 21 & 7 & ornaments \\
\hline 4059 & $\mathrm{f}$ & 4 & y & 157.6 & 5 & $\mathrm{n}$ & $\mathrm{n}$ & $\mathrm{n}$ & $\mathrm{n}$ & $\mathrm{n}$ & 2.36 & $\mathrm{n}$ & $\mathrm{y}$ & & & & 0 & 0 & 0 & none \\
\hline 4105 & $\mathrm{f}$ & 4 & $\mathrm{n}$ & 148.8 & & $\mathrm{n}$ & $\mathrm{n}$ & $\mathrm{n}$ & $\mathrm{n}$ & $\mathrm{n}$ & 1.97 & $\mathrm{n}$ & $\mathrm{y}$ & & & & 1 & 1 & 0 & none \\
\hline 4106 & $\mathrm{f}$ & 3 & y & 160.9 & & $\mathrm{n}$ & y & $\mathrm{y}$ & $\mathrm{n}$ & $\mathrm{n}$ & 2.08 & $\mathrm{n}$ & $\mathrm{y}$ & & & & 3 & 3 & 0 & none \\
\hline 4083 & $\mathrm{f}$ & 1 & $\mathrm{n}$ & & & $\mathrm{n}$ & $\mathrm{n}$ & $\mathrm{n}$ & $\mathrm{n}$ & $\mathrm{n}$ & 2.06 & $\mathrm{n}$ & $\mathrm{y}$ & & & & 5 & 5 & 0 & none \\
\hline 3499 & $\mathrm{f}$ & 3 & y & 158.5 & 0 & $\mathrm{y}$ & y & $\mathrm{y}$ & $\mathrm{n}$ & $\mathrm{n}$ & 2.79 & $\mathrm{n}$ & $\mathrm{y}$ & y & & & 7 & 11 & 4 & ornaments \\
\hline 4013 & $\mathrm{f}$ & & $\mathrm{n}$ & 160.8 & 0 & $\mathrm{n}$ & $\mathrm{n}$ & $\mathrm{n}$ & $\mathrm{n}$ & $\mathrm{n}$ & 2.65 & $\mathrm{n}$ & $\mathrm{y}$ & y & & & 2 & 3 & 1 & ornaments \\
\hline 4045 & $\mathrm{f}$ & 1 & $\mathrm{n}$ & 151.5 & 1 & $\mathrm{n}$ & $\mathrm{y}$ & $\mathrm{y}$ & $\mathrm{n}$ & $\mathrm{n}$ & 2.28 & $\mathrm{n}$ & $\mathrm{y}$ & y & & & 0 & 1 & 1 & ornaments \\
\hline 4020 & $\mathrm{f}$ & & & 153.0 & & $\mathrm{n}$ & $\mathrm{y}$ & $\mathrm{y}$ & $\mathrm{n}$ & $\mathrm{n}$ & 2.57 & $\mathrm{n}$ & $\mathrm{y}$ & y & & & 1 & 1 & 0 & none \\
\hline 4065 & $\mathrm{f}$ & 3 & $\mathrm{n}$ & 152.7 & 0 & $\mathrm{n}$ & $\mathrm{n}$ & $\mathrm{n}$ & $\mathrm{y}$ & $\mathrm{y}$ & 3.26 & $\mathrm{y}$ & $\mathrm{y}$ & y & $\mathrm{y}$ & & 0 & 0 & 0 & none \\
\hline 4035 & $\mathrm{f}$ & & & 157.4 & 0 & $\mathrm{n}$ & $\mathrm{n}$ & $\mathrm{n}$ & $\mathrm{n}$ & $\mathrm{n}$ & 2.82 & $\mathrm{n}$ & $\mathrm{y}$ & y & $\mathrm{y}$ & & 0 & 0 & 0 & none \\
\hline 4026 & $\mathrm{f}$ & 1 & $\mathrm{y}$ & 158.3 & 1 & $\mathrm{n}$ & $\mathrm{y}$ & $\mathrm{n}$ & y & $\mathrm{n}$ & 2.92 & $\mathrm{n}$ & $\mathrm{y}$ & y & $\mathrm{y}$ & & 0 & 0 & 0 & none \\
\hline 4034 & $\mathrm{f}$ & 1 & y & 154.7 & 5 & y & $\mathrm{y}$ & $\mathrm{n}$ & $\mathrm{n}$ & $\mathrm{n}$ & 2.51 & $\mathrm{n}$ & $\mathrm{y}$ & y & $\mathrm{y}$ & & 1 & 2 & 1 & ornaments \\
\hline 4084 & $\mathrm{f}$ & 2 & & 144.3 & & $\mathrm{n}$ & $\mathrm{y}$ & $\mathrm{n}$ & $\mathrm{y}$ & $\mathrm{n}$ & 3.27 & $\mathrm{n}$ & $\mathrm{y}$ & $\mathrm{y}$ & $\mathrm{y}$ & & 0 & 0 & 0 & none \\
\hline 4033 & $\mathrm{~m}$ & 3 & $\mathrm{n}$ & & 1 & $\mathrm{n}$ & $\mathrm{y}$ & $\mathrm{y}$ & $\mathrm{n}$ & $\mathrm{n}$ & 1.87 & $\mathrm{n}$ & $\mathrm{y}$ & & & & 0 & 1 & 1 & other \\
\hline 4085 & $\mathrm{~m}$ & 3 & $\mathrm{n}$ & 166.8 & 2 & $\mathrm{y}$ & $\mathrm{y}$ & y & $\mathrm{n}$ & $\mathrm{n}$ & 2.52 & $\mathrm{y}$ & $\mathrm{y}$ & & & & 0 & 0 & 0 & none \\
\hline 3720 & $\mathrm{~m}$ & 1 & $\mathrm{n}$ & 157.2 & 5 & $\mathrm{n}$ & $\mathrm{n}$ & $\mathrm{n}$ & $\mathrm{y}$ & y & 2.16 & $\mathrm{n}$ & $\mathrm{y}$ & & & & 2 & 3 & 1 & other \\
\hline 4093 & $\mathrm{~m}$ & 3 & y & 169.8 & 8 & $\mathrm{y}$ & $\mathrm{y}$ & $\mathrm{y}$ & $\mathrm{n}$ & $\mathrm{n}$ & 2.39 & $\mathrm{n}$ & $\mathrm{y}$ & & & & 0 & 0 & 0 & none \\
\hline 4040 & $\mathrm{~m}$ & 0 & $\mathrm{n}$ & 168.1 & 10 & $\mathrm{n}$ & $\mathrm{n}$ & $\mathrm{n}$ & $\mathrm{y}$ & $\mathrm{y}$ & 3.32 & $\mathrm{y}$ & $\mathrm{y}$ & & & & 0 & 4 & 4 & weapon \\
\hline 4029 & $\mathrm{~m}$ & 3 & y & 165.0 & 11 & $\mathrm{y}$ & $\mathrm{y}$ & y & $\mathrm{n}$ & $\mathrm{n}$ & 2.47 & $\mathrm{n}$ & $\mathrm{y}$ & & & & 0 & 0 & 0 & none \\
\hline 4027 & $\mathrm{~m}$ & 1 & $\mathrm{n}$ & 167.0 & 11 & $\mathrm{y}$ & $\mathrm{y}$ & y & $\mathrm{y}$ & $\mathrm{n}$ & 3.12 & $\mathrm{n}$ & $\mathrm{y}$ & & & & 0 & 0 & 0 & none \\
\hline 4016 & $\mathrm{~m}$ & 4 & $\mathrm{n}$ & 170.2 & & y & $\mathrm{n}$ & $\mathrm{n}$ & $\mathrm{n}$ & $\mathrm{n}$ & 2.54 & $\mathrm{n}$ & $\mathrm{y}$ & & & & 1 & 1 & 0 & none \\
\hline 3801 & $\mathrm{~m}$ & 2 & $\mathrm{n}$ & 155.6 & & $\mathrm{n}$ & $\mathrm{n}$ & $\mathrm{n}$ & $\mathrm{y}$ & $\mathrm{n}$ & 2.11 & $y$ & $\mathrm{y}$ & & & & 10 & 10 & 0 & none \\
\hline 4037 & $\mathrm{~m}$ & 2 & $\mathrm{n}$ & 172.7 & 0 & $\mathrm{n}$ & $\mathrm{n}$ & $\mathrm{n}$ & $y$ & $\mathrm{n}$ & 3.33 & $\mathrm{n}$ & $\mathrm{y}$ & y & & & 1 & 1 & 0 & none \\
\hline 4038 & $\mathrm{~m}$ & 0 & $\mathrm{n}$ & 162.7 & 0 & y & $\mathrm{y}$ & y & $\mathrm{n}$ & $\mathrm{n}$ & 2.4 & $\mathrm{y}$ & $\mathrm{y}$ & y & & & 3 & 4 & 1 & weapon \\
\hline 4051 & $\mathrm{~m}$ & 3 & $\mathrm{n}$ & 163.0 & 0 & $\mathrm{y}$ & $\mathrm{y}$ & $\mathrm{n}$ & $\mathrm{y}$ & $\mathrm{y}$ & 2.7 & y & $\mathrm{y}$ & y & & & 0 & 2 & 2 & armour \\
\hline 4025 & $\mathrm{~m}$ & 3 & $\mathrm{n}$ & 169.9 & 1 & y & $\mathrm{y}$ & y & $\mathrm{y}$ & $\mathrm{y}$ & 2.61 & $\mathrm{n}$ & $\mathrm{y}$ & y & & & 0 & 0 & 0 & none \\
\hline 3805 & $\mathrm{~m}$ & 2 & $\mathrm{n}$ & 168.7 & 4 & $\mathrm{n}$ & $\mathrm{y}$ & $\mathrm{n}$ & $\mathrm{y}$ & $y$ & 3.59 & $\mathrm{y}$ & $\mathrm{y}$ & y & & & 3 & 3 & 0 & none \\
\hline 4028 & $\mathrm{~m}$ & & & 168.2 & 0 & $\mathrm{n}$ & $\mathrm{y}$ & y & $\mathrm{y}$ & $\mathrm{n}$ & 3.14 & $\mathrm{n}$ & $\mathrm{y}$ & $\mathrm{y}$ & $\mathrm{y}$ & & 0 & 0 & 0 & none \\
\hline 4046 & $\mathrm{~m}$ & 3 & y & 167.2 & 0 & y & $\mathrm{y}$ & y & $\mathrm{n}$ & $\mathrm{n}$ & 2.92 & $y$ & y & y & $y$ & & 0 & 2 & 2 & weapon \\
\hline 4021 & $\mathrm{~m}$ & 2 & & 170.8 & 0 & $\mathrm{n}$ & $\mathrm{y}$ & $\mathrm{y}$ & $\mathrm{y}$ & $y$ & 3.14 & $\mathrm{y}$ & $\mathrm{y}$ & y & $\mathrm{y}$ & & 0 & 1 & 1 & strigil \\
\hline 4058 & $\mathrm{~m}$ & 2 & $\mathrm{n}$ & 164.2 & 2 & $\mathrm{n}$ & $\mathrm{y}$ & y & $\mathrm{y}$ & $\mathrm{n}$ & 3.6 & $\mathrm{y}$ & $\mathrm{y}$ & y & $\mathrm{y}$ & & 0 & 0 & 0 & none \\
\hline 4043 & $\mathrm{~m}$ & 1 & $\mathrm{n}$ & 166.5 & 3 & y & y & $\mathrm{n}$ & $y$ & $\mathrm{n}$ & 3.09 & $y$ & $\mathrm{y}$ & y & $\mathrm{y}$ & & 0 & 0 & 0 & none \\
\hline 4015 & $\mathrm{~m}$ & 4 & & 164.6 & 3 & $\mathrm{y}$ & $\mathrm{n}$ & $\mathrm{n}$ & $\mathrm{n}$ & $\mathrm{n}$ & 2.82 & $\mathrm{n}$ & $y$ & $\mathrm{y}$ & $\mathrm{y}$ & & 1 & 3 & 2 & $\begin{array}{l}\text { armour, } \\
\text { strigil }\end{array}$ \\
\hline 4039 & $\mathrm{~m}$ & 4 & $\mathrm{n}$ & 167.1 & 7 & $\mathrm{n}$ & y & y & y & y & 3.07 & $\mathrm{n}$ & $\mathrm{y}$ & y & $\mathrm{y}$ & & 1 & 3 & 2 & weapon \\
\hline
\end{tabular}




\begin{tabular}{|c|c|c|c|c|c|c|c|c|c|c|c|c|c|c|c|c|c|c|c|c|}
\hline \multirow[b]{2}{*}{ 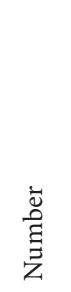 } & \multirow[b]{2}{*}{ ڤ্凶 } & \multicolumn{3}{|c|}{ Childhood } & \multicolumn{8}{|c|}{ Adult Experience } & \multicolumn{4}{|c|}{ Life Span } & \multicolumn{4}{|c|}{ Treatment at Death } \\
\hline & & 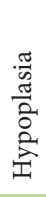 & 苞 & 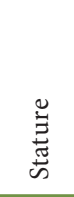 & 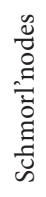 & 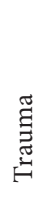 & 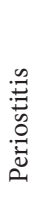 & 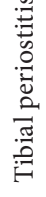 & ৫্ & 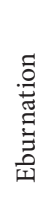 & 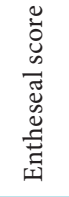 & 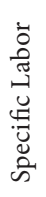 & $\begin{array}{l}0 \\
\text { 1 } \\
\text { రి }\end{array}$ & $\begin{array}{l}\text { 아 } \\
\text { 1 } \\
\text { o }\end{array}$ & $\begin{array}{l}0 \\
10 \\
1 \\
o \\
+1\end{array}$ & in & $\begin{array}{l}\frac{0}{0} \\
\frac{0}{\pi} \\
0 \\
0 \\
0\end{array}$ & $\begin{array}{l}0 \\
0 \\
0 \\
0 \\
0 \\
\pi \\
0 \\
0 \\
10\end{array}$ & 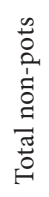 & 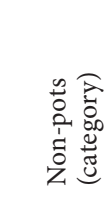 \\
\hline 4012 & $\mathrm{~m}$ & 2 & y & 160.3 & 7 & $\mathrm{n}$ & $\mathrm{n}$ & $\mathrm{n}$ & $\mathrm{y}$ & $\mathrm{n}$ & 2.82 & $\mathrm{n}$ & $\mathrm{y}$ & $\mathrm{y}$ & $\mathrm{y}$ & & 5 & 5 & 0 & none \\
\hline 4100 & $\mathrm{~m}$ & 3 & $\mathrm{n}$ & 162.4 & 7 & $\mathrm{n}$ & $\mathrm{y}$ & $\mathrm{y}$ & $\mathrm{y}$ & y & 3.23 & $\mathrm{y}$ & $\mathrm{y}$ & $\mathrm{y}$ & $\mathrm{y}$ & & 0 & 0 & 0 & none \\
\hline 3733 & $\mathrm{~m}$ & 1 & $\mathrm{n}$ & 175.6 & 10 & $\mathrm{n}$ & $\mathrm{n}$ & & $\mathrm{y}$ & y & 2.99 & $\mathrm{y}$ & $\mathrm{y}$ & $\mathrm{y}$ & $\mathrm{y}$ & & 2 & 2 & 0 & none \\
\hline 4018 & $\mathrm{~m}$ & 2 & $\mathrm{n}$ & 166.6 & & $\mathrm{y}$ & $\mathrm{y}$ & $\mathrm{y}$ & $\mathrm{y}$ & y & 2.82 & $\mathrm{y}$ & $\mathrm{y}$ & $\mathrm{y}$ & $\mathrm{y}$ & & 0 & 0 & 0 & none \\
\hline 4047 & $\mathrm{~m}$ & 1 & $\mathrm{n}$ & 169.8 & 0 & $\mathrm{y}$ & $\mathrm{y}$ & $\mathrm{y}$ & $\mathrm{y}$ & y & 3.13 & $\mathrm{y}$ & $\mathrm{y}$ & $\mathrm{y}$ & $\mathrm{y}$ & y & 0 & 1 & 1 & weapon \\
\hline 3533 & $\mathrm{~m}$ & 0 & $\mathrm{n}$ & 166.6 & 0 & $\mathrm{y}$ & $\mathrm{y}$ & $\mathrm{y}$ & y & y & 2.83 & $\mathrm{y}$ & $\mathrm{y}$ & $\mathrm{y}$ & $\mathrm{y}$ & y & 1 & 2 & 1 & armour \\
\hline 4042 & $\mathrm{~m}$ & & & 165.2 & 10 & $\mathrm{n}$ & y & $\mathrm{n}$ & $\mathrm{n}$ & $\mathrm{n}$ & 2.99 & $\mathrm{n}$ & $\mathrm{y}$ & $\mathrm{y}$ & $\mathrm{y}$ & $\mathrm{y}$ & 0 & 1 & 1 & other \\
\hline 4102 & $\mathrm{~m}$ & 3 & $\mathrm{n}$ & 168.6 & 11 & $\mathrm{n}$ & y & y & y & $\mathrm{n}$ & 3.04 & $\mathrm{n}$ & $\mathrm{y}$ & & & & 4 & 4 & 0 & none \\
\hline
\end{tabular}

Table 3. Gendered differences in skeletal markers.

\begin{tabular}{|c|c|c|c|}
\hline Stage of Life & Biographical Marker & Females & Males \\
\hline \multirow[t]{3}{*}{ Childhood } & Enamel hypoplasia & $\begin{array}{l}\text { 0-1 lesions: } 4 \\
\text { 2-3 lesions: } 8 \\
\text { 4+ lesions: } 4\end{array}$ & $\begin{array}{l}0-1 \text { lesions: } 8 \\
\text { 2-3 lesions: } 16 \\
\text { 4+ lesions: } 3\end{array}$ \\
\hline & Cribra orbitalia & $7 / 14(50 \%)$ & $4 / 25(16 \%)$ \\
\hline & Stature & Mean 155.7 & Mean 166.4 \\
\hline \multirow[t]{8}{*}{ Adult experience } & Schmorl's nodes & $\begin{array}{l}4 / 13 \text { individuals }(31 \%) \\
\text { Mean vertebrae affected } \\
\text { per person: } 0.92\end{array}$ & $\begin{array}{l}\text { 18/26 individuals }(69 \%) \\
\text { Mean vertebrae affected } \\
\text { per person: } 4.35\end{array}$ \\
\hline & Trauma & $2 / 18(11 \%)$ & $14 / 29(48 \%)$ \\
\hline & Periostitis & $7 / 18(39 \%)$ & $21 / 29(72 \%)$ \\
\hline & Tibial periostitis & $4 / 18(22 \%)$ & $17 / 28(61 \%)$ \\
\hline & $\mathrm{OA}$ & $3 / 17(18 \%)$ & $20 / 29(69 \%)$ \\
\hline & Eburnation & $1 / 17(6 \%)$ & $12 / 29(41 \%)$ \\
\hline & Entheseal score & Mean: 2.46 & Mean: 2.85 \\
\hline & Specialized labor & $1 / 17(6 \%)$ & $15 / 29(52 \%)$ \\
\hline Life span & Life span & $\begin{array}{l}20-30: 9(50 \%) \\
\text { 30-40: } 4(22 \%) \\
40-50: 5(28 \%) \\
50+: 0(0 \%)\end{array}$ & $\begin{array}{l}20-30: 9(32 \%) \\
30-40: 5(18 \%) \\
40-50: 11(39 \%) \\
50+: 3(11 \%)\end{array}$ \\
\hline \multirow[t]{4}{*}{ Response to death } & Total pots & Mean: 2.28 & Mean: 1.17 \\
\hline & Total other goods & Mean: 1.22 & Mean: 0.66 \\
\hline & Total goods & Mean: 3.50 & Mean: 1.83 \\
\hline & Kinds of other goods & Ornaments & $\begin{array}{l}\text { Weapons, armor, strigils, } \\
\text { few miscellaneous objects }\end{array}$ \\
\hline
\end{tabular}

shoulder dysfunction (Fig. 4). He had Schmorl's nodes in five vertebrae, implying an active physical regime, and was buried with normal rites, including for some reason an iron nail in his burial. A second individual (4025) had a probable subluxation of the right hip, which may have affected his gait. He also suffered traumas to the left ulna and radius and to his eighth thoracic vertebra, all healed; he died in his thirties and was buried without goods. The third (4029) suffered a fractured right femur midshaft that healed well but left his right leg angulated medially by about 15 degrees and $24 \mathrm{~mm}$ shorter than his left, probably affecting his 

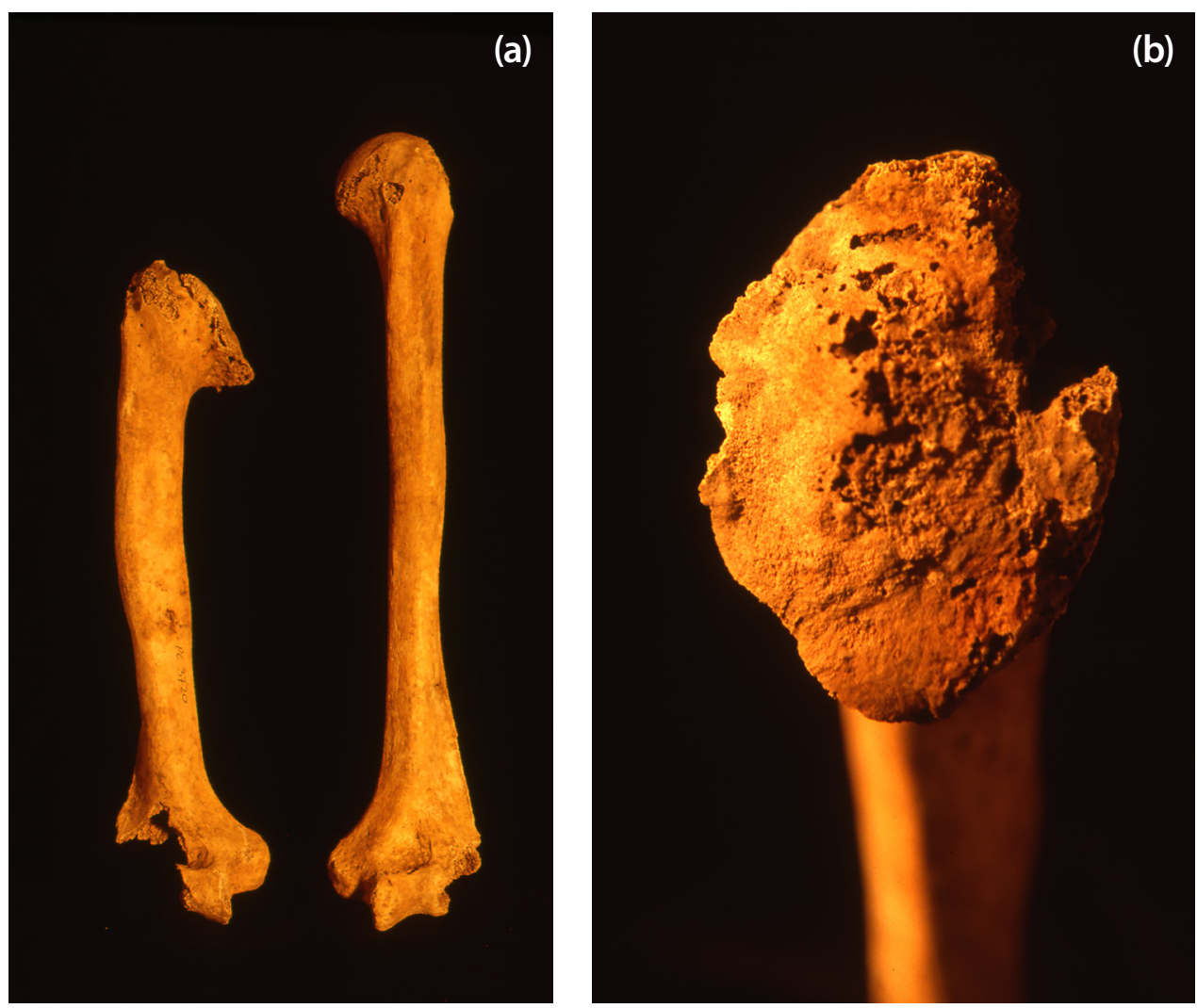

Figure 4. Congenital "humerus varus" condition, 3720: (a) right and left humeri; (b) proximal epiphysis, left humerus.

gait. He also had cribra orbitalia (unusually for a male in this sample), strong entheseal markings for his age, 11 vertebrae with Schmorl's nodes, and a healed blade cut to his right orbit. He died in his twenties.

All three men clearly had a high risk of injury and physical stress, and none survived beyond his thirties, placing them at one end of the spectrum of adult male experience (see below) and suggesting perhaps that ordinary social life did not treat them kindly. On the other hand, all three men were buried in a more or less "normal" way, and the life risks they ran were not unique to them but shared with other men. This suggests that they were not categorically excluded or stigmatized; as Laes (2018) comments for the Roman period, people with such impairments may have experienced pain and been socially marked or disadvantaged, but they would also have been integrated into everyday social life.

\section{Adulthood: Women's Life Paths}

The Pontecagnano women in this sample seem a homogeneous group, at least skeletally (Table 2; Fig. 7). They display relatively few pathologies, traumas, or adaptations to marked physical stress. They clearly experienced serious life risks, as many of them died relatively early in adulthood. It is possible that some died in childbirth, but we cannot prove this. Their burials, however, give us some idea of the normative biography for women. Many women dying young had simple burials. For example, 4094 stands for many of them; a small, gracile woman, she died between 18 and 22 years of age and was buried with a single pot. But while 4019 had a similar life trajectory, her burial reveals both more wealth in life (if the gold and silver ornaments she wore in death belonged to her) and a more ostentatious expression of grief in the willingness to sacrifice such wealth permanently. The three women who had relatively lavish grave goods all died relatively young (4017 and 4019 in their twenties, 3499 between 30 and 35). Classical sources suggest that motherhood was an important component of women's identity, and it may be that such ceremonial expressions react to a "bad death" (Gnoli and Vernant 1982), a sense of losing this opportunity; perhaps they mark a woman dying without children (daughters, or sons who might marry) to whom she could pass on her personal gendered wealth. In contrast, older women generally received relatively simple burials. Classical women are often shown in art as authoritative matriarchs at the center of a family (Leader 1997); it seems likely that women's age was valued, but it was expressed in ways other than burial. 
There were also variations from this common pathway. Some may reflect individual variation. Individual 4084 was a very small woman $(144.3 \mathrm{~cm})$ with enamel hypoplasias reflecting two severe episodes of stress in childhood. She survived until her forties; when she died, she had osteoarthritis in her cervical vertebrae, a healed periosteal lesion on her left femur, an enthesopathy on her right bicipital tuberosity, and hyperostosis frontalis interna. None of these necessarily speak of a life of poverty or marginality. Other variations probably reflect work patterns. While Classical women, particularly among the poor, routinely did physical work including farm and industrial work, they performed specialized jobs less often than did men. Three women in this group $(3838,4059,4015)$ display a pattern of early death with many hypoplasias, cribra orbitalia, and/or reduced stature, perhaps suggesting particular poverty. Given how rare it is for women in this group to display Schmorl's nodes, it is striking that 4059 had five vertebrae affected by them before she died between 18 and 22; this may mark her as performing especially heavy work. In contrast, 4065 appears the best candidate for a woman undertaking specialized work. She displays osteoarthritis in her hands, feet, and neck (the latter with eburnation), but not her back, suggesting that it is not simply due to age-related degeneration. Her entheseal markings are idiosyncratically varied, with particularly marked common extensors and flexors bilaterally, and, interestingly, marked insertions for the lateral pterygoid muscles. Her left first metacarpal displays a $10 \mathrm{~mm}$ palmar outgrowth at its base which may be due to a functional extension or a poorly healed avulsion fracture. These may suggest that she habitually engaged in some specialized activity before she died in her forties, perhaps some craft production. Interestingly, neither she nor 4059 were accorded particular burial treatment. This may suggest that, while particular forms of women's work may have been valued, physical work per se did not form part of a woman's identity in the same way it did men's.

\section{Adulthood: Men's Divergent Life Paths}

The Pontecagnano male skeletons seem both "busier" and more varied, in complicated ways. The effect of age is surprisingly minimal. We might expect both age-related phenomena such as osteoarthritis and lesions such as traumas and periosteal deposition (which accumulate in the skeleton over time) to show a clear relationship with age at death-a version of the "osteological paradox" (Wood et al. 1992). Indeed, this is the case with dental disease (caries and antemortem loss) in this sample, which clearly progresses with age. But systematic screening shows no significant relationship between most of the skeletal features considered here and age in males. The only exception is the average entheseal score, and even this is much less closely associated with age in men $\left(\mathrm{r}^{2}=0.264\right)$ than it is in women, among whom it shows a quite close relationship $\left(r^{2}=0.723\right)$ (Fig. 5). While entheseal marking increased with age in all men, in some men this happened gradually, while others began experiencing noticeable entheseal changes as soon as they achieved adulthood, if not before; the age at onset is confirmed by men dying in their twenties with high entheseal markings (Fig. 5). The same thing can be seen with Schmorl's nodes. Interestingly, there seems to have been a difference between males with five or fewer Schmorl's nodes (principally involving lumbar vertebrae, perhaps for biomechanical causes [Plomp et al. 2012, 2015]) and those with more than five which implies substantial thoracic involvement (Fig. 6). Overall,
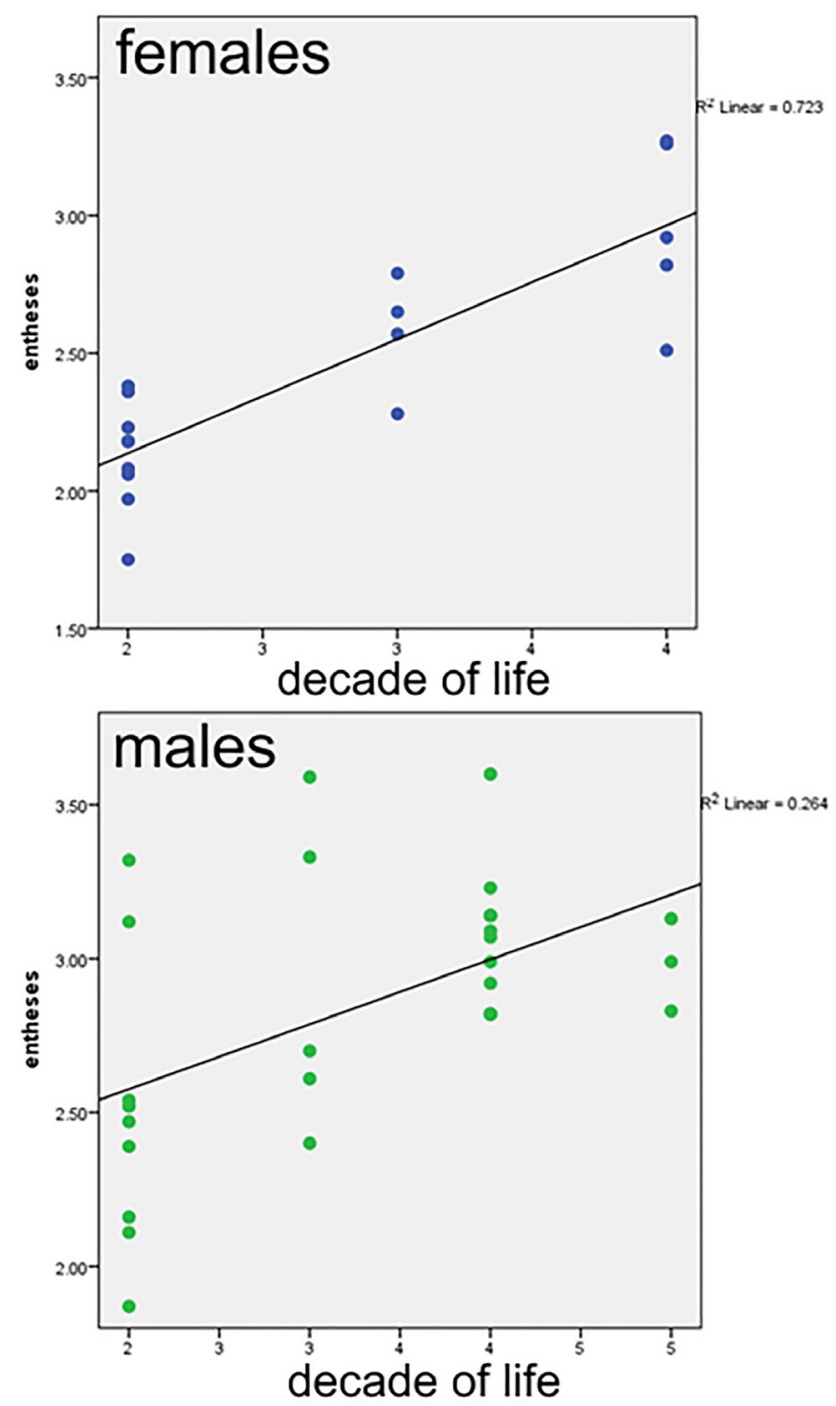

Fig. 5. Relationship between average entheseal scores and age at death. Top chart: women. Bottom chart: men. 


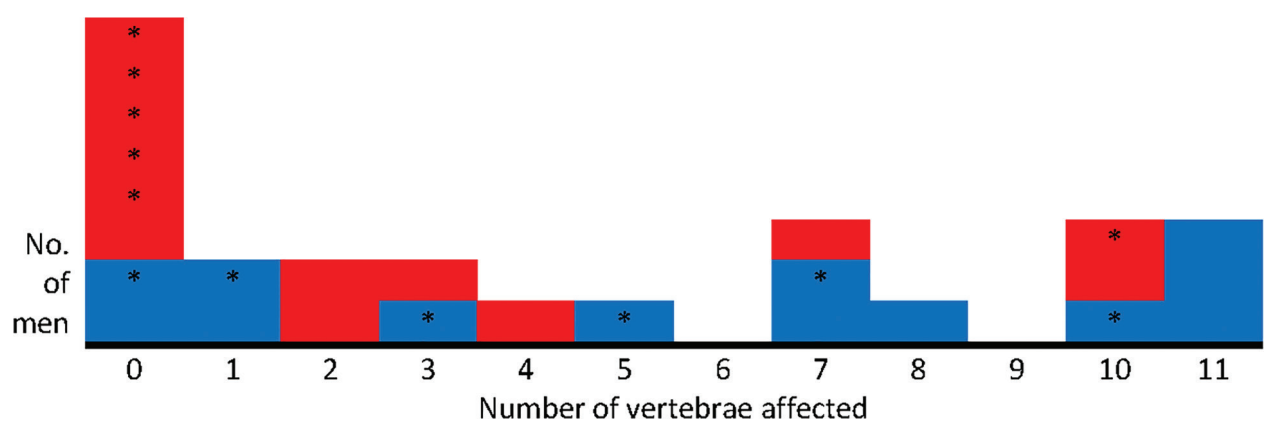

Fig. 6. The number of vertebrae affected by Schmorl's nodes in males; red shows individuals flagged as possibly performing specialized labor, blue shows individuals not flagged as such. Asterisks mark individuals buried with grave goods other than pottery vessels.

in the Pontecagnano sample, while some men dying older may have accumulated these lesions with age, others clearly experienced extensive spinal damage before dying in their twenties (Table 4). Skeletal degeneration, thus, did not simply mirror age. Some men may have followed high-impact lifestyles that placed heavy general stress upon the skeleton from the very beginning of adulthood, while others followed lower-impact lifestyles in which wear and tear accumulated more gradually.

But who were these men? Which pathway they traveled may have had some relation to their occupation. Ancient cities such as Pontecagnano had complex divisions of labor, with a wide range of recognized, fulltime occupations for males, most involving physical labor. Here, about half (15/29) of the male skeletons were identified as potentially having performed specialized work using the criteria described above. As noted above, this is merely an approximate, suggestive

Table 4. Schmorl's nodes in men from Pontecagnano. Gray $=$ skeletal evidence of possible specialized labor. Black $=$ none. ${ }^{*}=$ buried with grave goods other than pottery.

\begin{tabular}{lcccc}
\hline $\begin{array}{l}\text { Number of Thoracic } \\
\text { and Lumbar Vertebrae } \\
\text { with Schmorl's Nodes }\end{array}$ & $\begin{array}{c}\text { Dying } \\
20-30\end{array}$ & $\begin{array}{c}\text { Dying } \\
30-40\end{array}$ & $\begin{array}{c}\text { Dying } \\
40-50\end{array}$ & $\begin{array}{c}\text { Dying } \\
50+\end{array}$ \\
\hline 0 & 4037 & $\begin{array}{c}4038^{*} \\
4051^{*}\end{array}$ & $\begin{array}{l}4021^{*} \\
4028\end{array}$ & $3533^{*}$ \\
& & & $4046^{*}$ & \\
1 & $4033^{*}$ & 4025 & & \\
2 & 4085 & & 4058 & \\
3 & & & $4015^{*}$ & \\
4 & & 3805 & & \\
5 & $3720^{*}$ & & & \\
6 & & & 4012 & \\
7 & & & $4039^{*}$ & \\
& & & 4100 & \\
8 & 4093 & & & \\
9 & & & & $4042^{*}$ \\
10 & $4040^{*}$ & 3733 & & \\
11 & 4027 & & & \\
& 4029 & & & \\
\hline
\end{tabular}

categorization, but it helps to identify those skeletons with unusual, potentially activity-related features. "Specialization" has a complex relationship with Schmorl's nodes (recall that the two were separated analytically here as variables independent from each other). The distribution of Schmorl's nodes in men is clearly bimodal (Fig. 6): 16 men had 0-5 lesions, while 10 had 6-11 lesions. Men with no or few Schmorl's nodes were more likely to be "specialists"; men with many Schmorl's nodes were more likely not to be "specialists" (Fig. 6). This suggest that some men habitually performed activities placing generalized stress upon the back, while others performed physically forceful but much more specific activities.

A few examples can give a human sense of such patterns. At one pole are individuals such as 4027, 4029, 4093, and 4102, who died young showing signs of hard physical labor. For example, by the time he died between 20 and 25 years of age, 4027 already had strong entheseal markings for his age (particularly torso musculature such as the erector spinae), 11 vertebrae marked by Schmorl's nodes, and osteoarthritis in his spine, neck, and acromia, not to mention having broken five right ribs which were probably fractured in a single episode and subsequently healed. In such cases, ongoing entheseal damage, joint degeneration, and minor back injuries were unlikely to have caused their deaths directly, almost all traumas observed were healed, and their early age at death probably bespeaks other life risks in addition to these stresses, suggesting hard or hazardous lives. Men such as these, dying in their twenties with heavily stressed skeletons, were often buried without grave goods.

At the other pole are individuals such as 3533,4021 , 4028 , and 4047. These men show signs of specialized work regimes, lived relatively longer lives, and were buried with prestigious objects. For example, 4021 died in his forties with no Schmorl's nodes or trauma, but he displays highly varied and idiosyncratic enthesopathies, unilateral eburnation marking lateral compression of the neck, asymmetry of the thorax with slight, hardly noticeable scoliosis, strongly asymmetrical 
arms, and ankyloses of the first ribs and sternum. He also had time to develop generalized periostitis and moderate osteoarthritis in the spine and shoulders. He was buried with a strigil, a reference to the urban, socially aspirational masculine culture of the gymnasium (Robb and Harris 2013:chapter 4). Five or six other men in the sample display similar patterns. We must be cautious about interpreting relations between possible work specialization and age at death, as some of the evidence for work patterns (entheseal markings and arthropathies) becomes more distinct and legible with advancing age. But at least some younger men's skeletons show that differentiated activities could leave traces in the skeleton already from early adulthood. At death, men identified as possibly performing specialized work may have been buried more often with weapons, armor, or strigils (Table 2). One might expect athletic equipment such as strigils to be associated with younger men rather than with men in their thirties, forties, and fifties, and there is no clear association between being buried with weapons or armor and skeletal evidence of actual violence (Table 5). Instead, these grave goods probably refer to ideals of masculinity and to social identity or community position.

But before we simply divide Pontecagnano males into laborers crushed by toil and upwardly mobile craft specialists, it is worth looking at variations too. We may perhaps identify generalized workers living to old age; for instance, 4042 lived into his fifties with no particular signs of activity beyond 10 Schmorl's nodes. Conversely, some men with "specialized" skeletons died in early or middle adulthood. Individual 4051 died in his thirties with no Schmorl's nodes but with an unusual pattern of activity markers. He habitually flexed his head, creating an articular facet for the occipital on C2; this was accompanied by a buttonlike callosity on the back of the sacrum, hyperflexion in his hips (with extension of the articular surface on to the anterior neck of the femurs) and ankles (with well-expressed hyperflexion facets on both distal tibiae), alteration of the shape of the left patella, and strongly lateralized arms with eburnation at the right acromion. His three broken ribs may not have been related to whatever activities created this suite of skeletal changes. He was buried with a large metal belt (a high-status male object related to armor) and some hooks. The body of 3085 was marked above all by activity in the mouth and head region, shown by dental grooving between many teeth (something almost unique in this group), the development of two separate wear planes on his anterior teeth, strong development of the temporal muscles, and osteoarthritis evidencing downward pressure on the left side of the neck. This was accompanied by eburnation in the manual phalanges, general osteoarthritis in the neck, thoracic spine, and elbows, and periostitis in the right fibula and right olecranon fossa. When he died in his thirties he was buried with three pottery vessels. Such variations suggest that men's life paths were not rigid or categorical tracks but fuzzy envelopes of possibilities.

How far can we go in interpreting life paths among these men? Some skeletons offer few hooks on which to hang a biographical narrative. Individual 4028, who died in his forties with active periostitis in his lower legs and enthesopathies at the insertions of his left gluteus maximum and adductor magnus, was buried without grave goods. Such men either followed other patterns of activity or did not trigger the biological processes creating clear skeletal data. Others offer, if anything, too much information. Individual 4038 is not particularly large $(162 \mathrm{~cm})$, and his skeleton is not marked by Schmorl's nodes or by particularly developed entheseal markings. It is not clear why both his humeral shafts are bent outward by 5-10 degrees. But he shows old fractures of his lower right third molar and left clavicle, and his skull shows a clear perimortem trauma from a strong blow to the left parietal with some blunt instrument, creating a blown-out circular perforation with internal beveling, radiating fractures, and no signs of healing (Robb 1997: Fig. 5.3). When he died in his thirties, 4038 he was buried with three pots and an iron blade. Perhaps the most dramatic skeleton is 4040 (see Robb 1994). He was a young man who lived until 25-30. Even in his short adult life, he had

Table 5. Grave goods and trauma in Pontecagnano males

\begin{tabular}{|c|c|c|c|c|}
\hline & & \multicolumn{3}{|c|}{ Trauma Related to Violence } \\
\hline & & None & Possible & Probable \\
\hline \multirow{3}{*}{$\begin{array}{l}\text { Grave goods related } \\
\text { to violence or } \\
\text { masculinity }\end{array}$} & None & 16 individuals & 4027 (ribs) & $\begin{array}{l}4016 \text { (cranial) } \\
4029 \text { (cranial) }\end{array}$ \\
\hline & Possible & $\begin{array}{l}4021 \text { (strigil) } \\
4047 \text { (knife) }\end{array}$ & $\begin{array}{l}3533 \text { (boxer's fracture; } \\
\text { metal sheet) }\end{array}$ & \\
\hline & Probable & $\begin{array}{l}4015 \text { (metal belt, strigil) } \\
4021 \text { (strigil) } \\
4039 \text { (blade) } \\
4040 \text { (point) }\end{array}$ & 4051 (ribs; metal belt) & $\begin{array}{l}4038 \text { (cranial, } \\
\text { perimortem; blade) } \\
4046 \text { (cranial; point) }\end{array}$ \\
\hline
\end{tabular}


acquired a long suite of skeletal changes. These included strongly marked entheses for his age and vertebrae with 10 Schmorl's nodes, but also many more specific markers: severely worn anterior teeth, entheses showing very strong flexion and abduction of both arms, an osteophyte on the coronoid process limiting flexion of his left ulna, strong flexion of the fingers, enthesopathies at the insertion of erector spinae, ankylosis of the third and fourth thoracic vertebrae, a button-like callosity on the posterior sacrum, eburnation of the head of right first metatarsal, and flattened heads of the metatarsals. These do not all have to refer to a single activity or occupation, but they form a unique set in this group, and they also show that specialized activity may have involved very forceful physical stress and may be evident already in early adulthood. When he died, 4040 was buried with an iron lance point, a fibula, and a pendant made from a boar tooth.

\section{Imagining Ancient Lives}

This article is experimental; it will have succeeded if it gives the reader the sense of having encountered the people of Pontecagnano as people rather than as skeletons and if it gives a sense of both the common patterns and the different tracks their lives followed as they unfolded. I have intentionally tried to write in terms a historian or anthropologist might use to talk about people rather than terms an osteologist would use to talk about skeletons. Much as Barrett and Blakey (2011) have done with enslaved Africans in early New York, I have also tried to juxtapose multiple osteobiographies to give a sense of the major issues, challenges, or range of life experience people had.

In interpreting these people's lives, I have tried to walk carefully between two extremes. One is overformalizing-for instance, by trying to rigidly typologize skeletons into formally defined groups. Biological data always have variation due to multiple causes, and assigning individuals to categories automatically moves everything else we know about them into the background, simplifying our understanding of them. The other extreme is over-concretizing. Osteobiography traditionally focuses upon adding as much detail as possible about individual subjects. It is tempting to imagine 4016 as a well-off and attractive young woman dying before her marriage or in childbirth, or 4065 as an older woman sitting at a loom. Individual 4059 could be a dependent or a slave, hauling heavy jugs of water for a large household all day, with 4027 her male equivalent, toiling at backbreaking unskilled labor. Individual 4051 squats, head bent intently and legs akimbo, over his workbench or potter's wheel, while 4040 hauls at the oars of a galley. All of these are entirely plausible for the historical context and skeletal data; none of them are the only possible pictures the data allow. But beyond the risk of drawing unwarranted conclusions, focusing upon single individuals and their individual stories loses the sense of how human lives unfolded generally within this community.

When we juxtapose many biographies, what really emerges is the texture of social process. At Pontecagnano, children were placed on gendered tracks at birth, giving them different life chances and risks. These gendered pathways were conditioned not merely by biological difference but above all by social differences regarding ideas of the life trajectory and activities appropriate to male and female lives. Childhood seems not to have had a strong influence on adult trajectory, provided one survived it. Physical limitations did not place individuals outside the range of ordinary activity and burial. Once they reached adulthood, women had more homogeneous life paths. There is some differentiation both in terms of evident wealth and physical stress, but there are not marked discontinuities among the women in this sample. Their deaths were most marked in terms of gender and wealth in early adulthood; physical work seems not to have been a strongly salient part of their identity as it was among men. Men's lives were more differentiated, and they seem to have become so immediately from the onset of adulthood, if not before. If there were strong or rigid categories, they may have been legal or political (e.g., servitude or economic dependency) rather than simply mapped on to activity regime, and are invisible to us now. What we see, instead, is a spectrum. Some men performed stressful general labor, and many of them died young. Some men probably performed specialized labors, and they may have had a greater chance of living longer and being buried with markers of masculinity, social aspiration, or position. But it would be misleading here to speak of rigid social differences, for example between artisans and laborers; even within this small sample from a limited segment of the social spectrum whose lives were far more similar than they were different, we see men exemplifying all variants on these possible tracks.

Life tracks provide fuzzy, non-deterministic envelopes rather than narrow pathways. They should leave statistical patterns in large samples. In small samples, as we lose the ability to nail down correlations statistically, we gain the ability to think about the people we study as individuals. Hence a map of our subjects' life courses shows tendencies, bundles of trajectories, but also a tangle of interweaving lives (Fig. 7). These represent the result of not only social position but also biological variation, contingency, and social movement. And there is no reason to suppose that these histories would not have been discursively available to people 


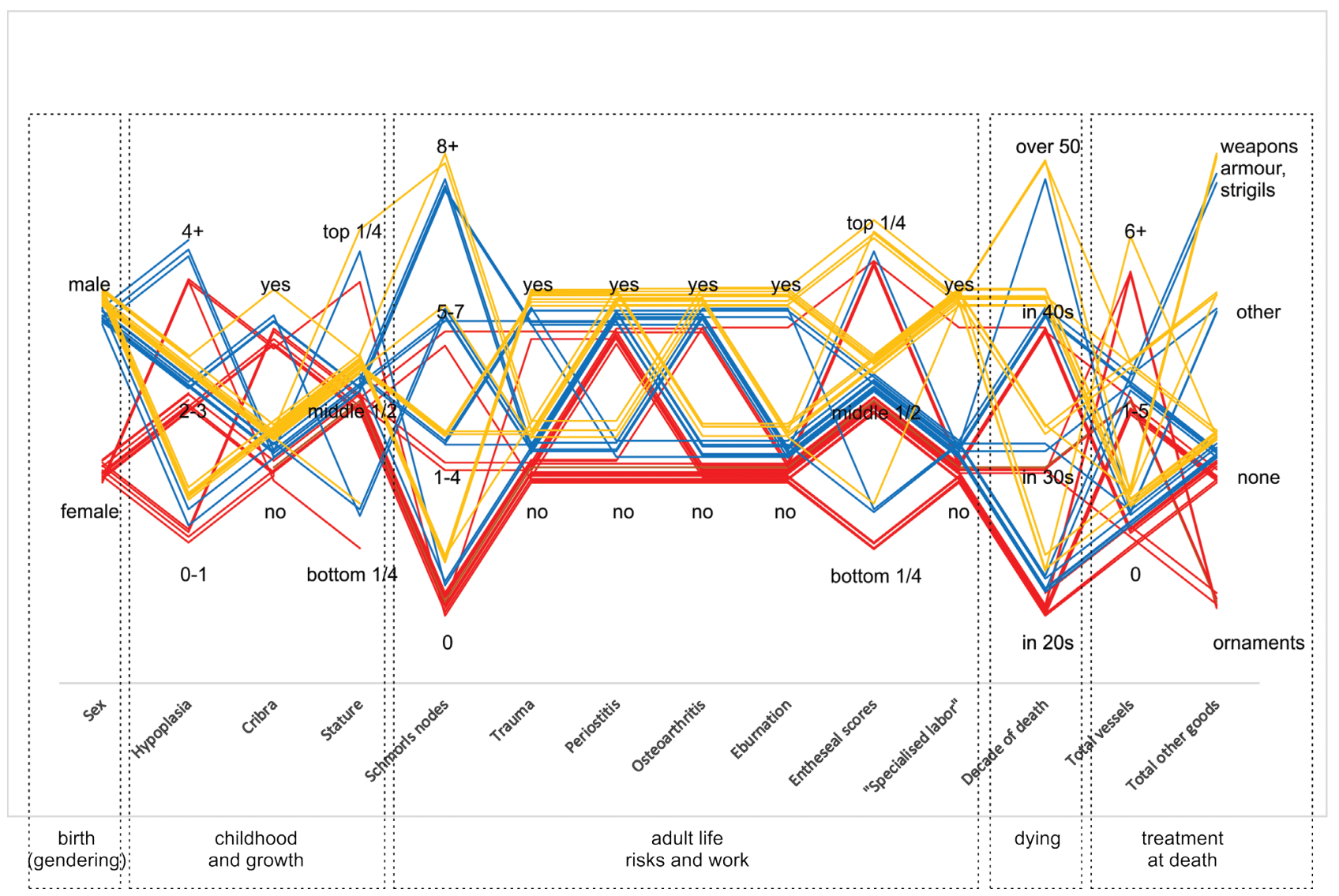

Fig. 7. Comparative life paths for Pontecagnano individuals. Women's lives are shown as red lines; men are divided into those whose skeletons were considered to show signs of possible specialized labor (yellow lines) and those whose do not (blue lines).

in ancient societies, at least as ideals of normative lives and the situated histories of how far individuals were able to negotiate the challenges they faced.

\section{Acknowledgments}

I am grateful to the Museo Nazionale di Antropologia, Firenze, for permission to study the skeletons from Pontecagnano, and to colleagues who helped with that research: Vitaliano Rossi, Caterina Scarsini, Renzo Bigazzi, Fiorenza Sonego, and Luca Lazzarini. Sarah Inskip and Piers Mitchell provided helpful advice on this manuscript. Nick Zair provided linguistic advice. All errors and misinterpretations remain my own. Funding for data collection was provided by the Wenner-Gren Foundation for Anthropological Research; theoretical concepts involved were partly developed under the aegis of Wellcome Trust Collaborative Grant (Collaborative Grant 200368/Z/15/A). I am very grateful to several anonymous reviewers whose thoughtful and detailed comments have substantially improved the manuscript.

\section{References Cited}

Agarwal, Sabrina C. 2016. Bone morphologies and histories: Life course approaches in bioarchaeology. American Journal of Physical Anthropology Supplement: Yearbook of Physical Anthropology 159(S61):130-149. DOI: 10.1002/ajpa.22905.

Agarwal, Sabrina C., and Patrick Beauchesne. 2011. It is not carved in bone: Development and plasticity of the aged skeleton. In Social Bioarchaeology, edited by Sabrina C. Agarwal and Bonnie A. Glencross. Blackwell, Chichester, pp. 312-331.

Alfano, Donatella, Paola Aurino, Francesco Basile, Elena Caracciolo, Maria D'Andrea, Carmine Pellegrino, Amadeo Rossi, and Monica Viscione. 2006. Pontecagnano tra Etruschi, Sanniti e Romani: Gli scavi dell'Università di Salerno e dell'Università di Napoli “L’Orientale" lungo l'autostrada SA-RC. In Verso la città: Forme insediative in Lucania e nel mondo italico fra IV e III sec. a.C., edited by Massimo Osanna. Osanna, Venosa, pp. 463-496.

Appleby, Joanna. 2011. Why we need an archaeology of old age, and a suggested approach. Norwegian Archaeological Review 43(2):145-168. DOI: 10.1080/00293652.2010.531582.

Barrett, Autumn R., and Michael L. Blakey. 2011. Life histories of enslaved Africans in colonial New York: A bioarchaeological study of the New York African Burial Ground. In Social Bioarchaeology, edited by Sabrina C. Agarwal and Bonnie A. Glencross. Blackwell, Chichester, pp. 212-249.

Boutin, Alexis T., Gloria L. Nusse, Sabrina B. Sholts, and Benjamin W. Porter. 2012. Face to face with the past: Reconstructing 
a teenage boy from early Dilmun. Near Eastern Archaeology 75(2):68-79. DOI: 10.5615/neareastarch.75.2.0068.

Buikstra, Jane E., and Douglas H. Ubelaker, eds. 1994. Standards for Data Collection from Human Skeletal Remains. Arkansas Archaeological Survey Research Series 44, Fayetteville.

Capasso, Luigi, Kenneth Kennedy, and Cynthia Wilczak. 1999. Atlas of Occupational Markers on Human Remains. Edigrafital, Teramo.

Cencetti, Sandra. 1989. La necropoli di Pontecagnano (Salerno): Studio antropologico e paleodemografico di un campione del $V-I V$ sec. a.C. Thesis, Università di Firenze.

d'Agostino, Bruno. 1974. Il mondo periferico della Magna Grecia. In Popoli e civiltà dell'Italia antica, edited by B. D'Agostino, P. E. Arias, and G. Colonna. Biblioteca di Storia Patria, Rome, pp. 177-272.

Dutour, Olivier. 1986. Enthesopathies (lesions of muscular insertions) as indicators of the activities of Neolithic Saharan populations. American Journal of Physical Anthropology 71(2): 221-224. DOI: 10.1002/ajpa.1330710209.

Finnegan, M. 1978. Non-metric variation of the infracranial skeleton. Journal of Anatomy 125:23-37.

Fornaciari, Gino, M. Brogi, and E. Balducci. 1984. Patologia dentaria degli inumati di Pontecagnano (Salerno), VII-IV sec. a.C. Archivio per l'Antropologia e la Etnologia 114:73-93.

Fornaciari, Gino, M. Brudi, and E. Balducci. 1986. Dental pathology of the skeletal remains of Pontecagnano, Salerno, Italy: 7th-4th c. B.C. Ossa 12:9-31.

Foxhall, Lin. 2013. Studying Gender in Classical Antiquity. Cambridge University Press, Cambridge.

Geller, Pamela L. 2017. The Bioarchaeology of Socio-Sexual Lives: Queering Common Sense about Sex, Gender, and Sexuality. Springer, Cham.

Glencross, Bonnie A. 2012. Skeletal injury across the life course: Towards understanding social agency. In Social Bioarchaeology, edited by Sabrina C. Agarwal and Bonnie A. Glencross. Blackwell, Chichester, pp. 390-409.

Gnoli, Gherardo, and Jean-Pierre Vernant. 1982. La mort, les morts dan les sociétés anciennes. Cambridge University Press/ Editions de la Maison des Sciences de l'Homme, Cambridge/ Paris.

Golden, Mark. 2003. Childhood in ancient Greece. In Coming of Age in Ancient Greece: Images of Childhood from the Classical Past, edited by Jenifer Neils and John H Oakley. Yale University Press, New Haven, CT, pp. 13-30.

Goodman, Alan, and Jerome Rose. 1991. Dental enamel hypoplasias as indicators of nutritional stress. In Advances in Dental Anthropology, edited by Mark A. Kelley and Clark Spencer Larsen. Wiley-Liss, New York, pp. 279-294.

Halcrow, Siân E., and Nancy Tayles. 2011. The bioarchaeological investigation of children and childhood. In Social Bioarchaeology, edited by Sabrina C. Agarwal and Bonnie A. Glencross. Blackwell, Chichester, pp. 333-359.

Hawkey, Diane E., and Charles F. Merbs. 1995. Activity-induced musculoskeletal stress markers (MSM) and subsistence strategy changes among ancient Hudson Bay Eskimos. International Journal of Osteoarchaeology 5(4):324-338. DOI: 10.1002 /oa.1390050403.

Heinz, Walter R., and Helga Krüger. 2001. Life course: Innovations and challenges for social research. Current Sociology 49(2):29-45. DOI: 10.1177/0011392101049002004.

Henderson, Charlotte Y., Valentina Mariotti, Doris Pany-Kucera, Sebastien Villotte, and Cynthia Wilczak. 2016. The new "Coimbra Method": A biologically appropriate method for recording specific features of fibrocartilaginous entheseal changes. International Journal of Osteoarchaeology 26(5):925-932. DOI: 10.1002/oa.2477.
Hollimon, Sandra. 2011. Sex and gender in bioarchaeological research: Theory, method and interpretation. In Social Bioarchaeology, edited by Sabrina C. Agarwal and Bonnie A. Glencross. Blackwell, Chichester, pp. 149-181.

Jurmain, Robert. 1998. Stories from the Skeleton: Behavioral Reconstruction in Human Osteology. Gordon and Breach, Amsterdam.

Jurmain, Robert, Francisca Alves Cardoso, Charlotte Henderson, and Sébastien Villotte. 2012. Bioarchaeology's holy grail: The reconstruction of activity. In A Companion to Paleopathology, edited by Anne L. Grauer. Wiley-Blackwell, Oxford, pp. 531-552.

Kacki, Sasha, Sebastian Villotte, and Christopher J. Knüsel. 2011. Baastrup's sign (kissing spines): A neglected condition in paleopathology. International Journal of Paleopathology 1(2):104110. DOI: 10.1016/j.ijpp.2011.09.001.

Kennedy, Kenneth. 1989. Skeletal markers of occupational stress. In Reconstruction of life from the skeleton, edited by Mehmet Yaşar İscan and Kenneth A. R. Kennedy. Liss, New York, pp. 129-160.

Kennedy, Kenneth A. R. 1998. Markers of occupational stress: Conspectus and prognosis of research. International Journal of Osteoarchaeology 8(5):305-310. DOI: 10.1002/(sici)1099 -1212(1998090)8:5<305::aid-oa444>3.0.co;2-a.

Kyere, Kwaku A., Khoi D. Than, Anthony C. Wang, Shayan U. Rahman, Juan M. Valdivia-Valdivia, Frank La Marca, and Paul Park. 2012. Schmorl's nodes. European Spine Journal 21(11): 2115-2121. DOI: 10.1007/s00586-012-2325-9.

Laes, Christian. 2018. Disability and the Disabled in the Roman World: A Social and Cultural History. Cambridge University Press, Cambridge.

Leader, Ruth E. 1997. In death not divided: Gender, family, and state on classical Athenian grave stelae American Journal of Archaeology 101(4):683-699. DOI: 10.2307/506830.

Lewis, Mary E. 2007. The Bioarchaeology of Children: Perspectives from Biological and Forensic Anthropology. Cambridge University Press, Cambridge.

Lombardi Pardini, Elena, G. Fulciniti, and Eduardo Pardini. 1992. Somatologia, dimorfismo sessuale e struttura biologica di una popolazione campana del VII-IV sec. a.C. Archivio per l'Antropologia e la Etnologia 121:3-43.

Lombardi Pardini, Elena, D. Polosa, and Eduardo Pardini. 1984. Gli inumati di Pontecagnano (Salerno), VII-VI sec. a.C. Archivio per l'Antropologia e la Etnologia 114:3-62.

Mallegni, Francesco, M. Brogi, and E. Balducci. 1984. Paleodontologia dei reperti umani di Pontecagnano (Salerno), VII-IV sec. a.C. Archivio per l'Antropologia e la Etnologia 114:63-93.

Mann, Robert W., and Sean P. Murphy. 1990. Regional Atlas of Bone Disease: A Guide to Pathologic and Normal Variation in the Human Skeleton. Charles C. Thomas, Springfield, IL.

Mattei, Tobias A., and Azeem A. Rehman. 2014. Schmorl's nodes: Current pathophysiological, diagnostic, and therapeutic paradigms. Neurosurgical Review 37(1):39-46. DOI: 10.1007/s10143 -013-0488-4.

Merbs, Charles F. 1983. Patterns of Activity Induced Pathology in a Canadian Inuit Population. Mercury Series, Archaeological Survey of Canada. National Museum of Man, Ottawa.

Ortner, Donald J., and Arthur C. Aufderheide. 1991. Human Paleopathology: Current Syntheses and Future Options. Smithsonian Institution Press, Washington DC.

Ortner, Donald J., and Walter G. J. Putschar. 1981. Identification of Pathological Conditions in Human Skeletal Remains. Smithsonian Institution Press, Washington, DC.

Pardini, Eduardo, Piero Mannucci, and Elena Lombardi Pardini. 1983. Sex ratio, età media di vita, mortalità differenziale per età e per sesso in una popolazione campana vissuta a Pontecagnano, Salerno, nei secoli VII-IV a.C. Archivio per l'Antropologia e la Etnologia 113:268-295. 
Pardini, Elena, Valentino Rossi, F. Innocenti, G. Stefanin, A. Fulgaro, and S. Patara. 1982. Gli inumati di Pontecagnano (Salerno), V-IV sec. a.C. Archivio per l'Antropologia e la Etnologia 112: 281-333.

Petrone, Pier Paolo. 1995. Analisi paleodemigrafica e paleopatologica delle tombe in proprietà Rossomando. In Pontecagnano II.3: Le nuove aree di necropoli del IV e III sec. a.C., edited by Antonia Serritella. Istituto Universitario Orientale, Napoli, pp. 129-134.

Plomp, Kimberley A., Charlotte A. Roberts, and Una Strand Vidarsdóttir. 2012. Vertebral morphology influences the development of Schmorl's nodes in the lower thoracic vertebrae. American Journal of Physical Anthropology 149 (4):572-582. DOI: 10.1002/ajpa.22168.

Plomp, Kimberley, Charlotte Roberts, and Una Vidarsdottir. 2015. Does the correlation between Schmorl's nodes and vertebral morphology extend into the lumbar spine? American Journal of Physical Anthropology 157(3):526-534. DOI: 10.1002/ajpa.22730.

Robb, John E. 1994. Skeletal signs of activity in the Italian metal ages: Methodological and interpretative notes. Human Evolution 9(3):215-229.

Robb, John. 1997. Violence and gender in early Italy. In Troubled Times: Osteological and Archaeological Evidence of Violence, edited by Debra L. Martin and David W. Frayer. CRC Press, Boca Raton, FL, pp.111-144.

Robb, John E. 1998. The interpretation of skeletal muscle sites: A statistical approach. International Journal of Osteoarchaeology 8(5):363-377. DOI: 10.1002/(SICI)1099-1212(1998090)8:5<363:: AID-OA438>3.0.CO;2-K.

Robb, John. 2002. Time and biography. In Thinking Through the Body: Archaeologies of Corporeality, edited by Yannis Hamilakis, Mark Pluciennik, and Sarah Tarlow. Kluwer/Academic, London, pp. 153-171.

Robb, John, Renzo Bigazzi, Luca Lazzarini, Caterina Scarsini, and Fiorenza Sonego. 2001. Social "status" and biological "status": A comparison of grave goods and skeletal indicators from Pontecagnano. American Journal of Physical Anthropology 115(3): 213-232. DOI: 10.1002/ajpa.1076.

Robb, John E., and Oliver Harris. 2013. The Body in History: Europe from the Paleolithic to the Future. Cambridge University Press, Cambridge.

Rogers, Juliet, and Anthony Waldron. 1995. A Field Guide to Joint Disease in Archaeology. Wiley, New York.

Rogers, Juliet, Tony Waldron, Paul Dieppe, and Iain Watt. 1987. Arthropathies in palaeopathology: The basis of classification according to most probable cause. Journal of Archaeological Science 14(2):179-193. DOI: 10.1016/0305-4403(87)90005-7.

Saul, Frank P., and Julie Mather Saul. 1989. Osteobiography: A Maya example. In Reconstruction of Life from the Skeleton, edited by Mehmet Yaşar İşcan and Kenneth A. R. Kennedy. Alan R. Liss, New York, pp. 287-301.

Scarsini, Caterina, and Renzo Bigazzi. 1995. Studio antropologico dei resti umani. In Pontecagnano II.3. Le nuove aree di necropoli del IV e III sec. a.C., edited by Antonia Serritella. Istituto Universitario Orientale, Napoli, pp. 135-146.

Serritella, Antonia, ed. 1995. Pontecagnano II.3: Le nuove aree di necropoli del IV e III sec. a.C. Istituto Universitario Orientale, Napoli.
Sofaer, Joanna, ed. 2000. Children and Material Culture. Routledge, London.

Sofaer, Joanna. 2006. The Body as Material Culture: A Theoretical Osteoarchaeology. Cambridge University Press, Cambridge.

Sofaer, Joanna. 2011. Towards a Social Bioarchaeology of Age. In Social Bioarchaeology, edited by Sabrina C. Agarwal and Bonnie A. Glencross. Blackwell, Chichester, pp. 285-311.

Sofaer, Joanna. 2013. Bioarchaeological approaches to the gendered body. In A Companion to Gender Prehistory, edited by Diane Bolger. John Wiley \& Sons, Chichester, pp. 226-243.

Sonego, Fiorenza. 1991. Lo stato di salute a Pontecagnano in un periodo di "crisi" (VII-1 meta V secolo a.C.): Analisi di indicatori scheletrici e dentari. Tesi di Laurea, Istituto di Antropologia, Università di Firenze.

Sonego, Fiorenza, and Caterina Scarsini. 1994. Indicatori scheletrici e dentari dello stato di salute e delle condizioni di vita a Pontecagnano (Salerno) nel VII-V sec. a.C. Bullettino di Paletnologia Italiana 85:1-25.

Stodder, Ann L. W., and Ann Palkovich, eds. 2012. The Bioarchaeology of Individuals. University of Florida Press, Gainesville.

Trinkaus, Erik. 1975. Squatting among the Neandertals: A problem in the behavioral interpretation of skeletal morphology. Journal of Archaeological Science 2(4):327-351. DOI: 10.1016 /0305-4403(75)90005-9.

Trotter, Mildred, and Goldine C. Gleser. 1958. A re-evaluation of estimation of stature based on measurements of stature taken during life and of long bones after death. American Journal of Physical Anthropology 16(1):79-123. DOI: 10.1002/ajpa.133 0160106.

Vida Navarro, Maria C. 1992. Warriors and weavers: Sex and gender in Early Iron Age graves from Pontecagnano. Journal of the Accordia Research Center 3:67-100.

Villotte, Sebastien, and Christopher J. Knüsel. 2013. Understanding entheseal changes: Definition and life course changes. International Journal of Osteoarchaeology 23(2):135-146. DOI: 10 .1002/oa.2289.

Waldron, Tony. 2012. Joint disease. In A Companion to Paleopathology, edited by Anne L. Grauer. Wiley-Blackwell, Oxford. pp. 515-530.

Weiss, Elizabeth. 1999. Sexual differences in activity patterns of a central Californian hunter-gatherer population. California Anthropologist 29:1-7.

Weiss, Elizabeth. 2007. Muscle markers revisited: Activity pattern reconstruction with controls in a central California Amerind population. American Journal of Physical Anthropology 133(3):931-940. DOI: 10.1002/ajpa.20607.

Weston, Darlene A. 2012. Nonspecific infection in paleopathology: Interpreting periosteal reactions. In A Companion to Paleopathology, edited by Anne L. Grauer. Wiley-Blackwell, Oxford, pp. 492-512.

Wood, James W., George R. Milner, Harry Harpending, and Kenneth M. Weiss. 1992. The osteological paradox: Problems in inferring prehistoric health from skeletal samples. Current Anthropology 33(4):343-370. DOI: 10.1086/204084.

Workshop of European Anthropologists. 1980. Recommendations for age and sex diagnoses of skeletons. Journal of Human Evolution 9(7):517-549. 